\title{
Reflexões sobre Interação e Colaboração a partir de um Curso Online
}

\section{Reflections on Interaction and Collaboration of an Online Course}

\author{
Sérgio Carrazedo Dantas* \\ Romulo Campos Lins ${ }^{* *}$
}

\begin{abstract}
Resumo
O interesse central deste estudo foi investigar processos de interação e de colaboração em uma comunidade online de professores de Matemática. Tomando como fundamentação teórica e metodológica o Modelo dos Campos Semânticos, procuramos dar visibilidade às características e à dinâmica das interações observadas. Para isso, desenvolvemos uma estrutura tecnológica que possibilitou que professores, envolvidos em um curso de difusão do conhecimento, intitulado Curso de GeoGebra, pudessem dialogar com seus pares, e, por meio de suas tomadas de decisões, estabelecer redes colaborativas. Alcançamos uma clara relação entre a autogestão, característica do modo de organização de uma comunidade online que criamos, e aquilo a que viemos designar de interação colaborativa.
\end{abstract}

Palavras-chave: Curso de GeoGebra, Interação. Colaboração. Interação colaborativa. Formação Continuada de Professores de Matemática.

\begin{abstract}
The central concern of this study was to investigate interaction and collaboration processes in an online community of mathematics teachers. Considering the Model of Semantic Fields as our theoretical and methodological foundation, we tried to give visibility to the characteristics and dynamics of interaction. In order to do so, we have developed a technological structure that made it possible for teachers involved in an extension course, to talk to their peers, and through their decision-making, establish their collaborative networks. We reached a clear characteristic of the self-management feature of the organizational processes of an online community that we created, and that which we called the collaborative interaction.
\end{abstract}

Keywords: Interaction. Collaboration. Collaborative interaction. Continued Education for Mathematics Teachers.

\footnotetext{
* Doutor em Educação Matemática pela Universidade Estadual Paulista (Unesp). Professor Adjunto da Universidade Estadual do Paraná (Unespar), Apucarana, Paraná, Brasil. Endereço para correspondência: Av. Minas Gerais, 5021, Caixa Postal: 98, CEP: 86800-970, Apucarana, Paraná, Brasil. E-mail: sergio.dantas@unespar.edu.br.

** Doutor em Educação Matemática pela University of Notthingam (Nottingham-Inglaterra). Professor Livre docente do Departamento de Educação Matemática e do Programa de Pós-Graduação em Educação Matemática da Universidade Estadual Paulista (Unesp), Rio Claro, São Paulo, Brasil. Endereço para correspondência: Av. 24-A, n. 1515, Bairro Bela Vista, CEP: 13506-900, Rio Claro, São Paulo, Brasil. E-mail: romlins@ @rc.unesp.br.
} 


\section{Introdução}

Em 2004, a World Wide Web, ou rede mundial de computadores, em termos técnicos deixou de ser referida como web 1.0 e passou a ser chamada de web 2.0. Não se tratava apenas de uma mudança de nome, mas de uma alteração qualitativa. Enquanto web 1.0, o usuário da rede era pensando como alguém que, navegando em um oceano de informações, podia ter acesso a textos, copiar arquivos, acessar dados em sites, entre outras ações. Era como se o usuário fosse um consumidor em um supermercado, onde buscava alguns suprimentos e sua vida não era afetada por grandes influências da Internet.

Na web 2.0 o usuário passou a ter participação na produção da rede. Por meio de novos programas e recursos, alguns integrados aos navegadores, essa fase é marcada por um aumento de velocidade de acesso e maior facilidade na produção de materiais para serem disponibilizados pelos usuários. Surgiram, então, os blogs e os softwares sociais ${ }^{1}$, conhecidos popularmente como redes sociais. Essa nova concepção de Internet teve reflexo imediato na forma como os usuários passaram a utilizá-la. Muitos passaram a ficar mais tempo conectados e a concentrar mais atividades nesse novo cenário de atuação: trocas de mensagens instantâneas, serviços bancários, comércio eletrônico, são alguns exemplos de novas funcionalidades da web 2.0.

À medida que aumentava a quantidade de usuários, surgiam novos serviços que tornavam os participantes da rede cada vez mais dependentes dos recursos oferecidos e, também, integrados a outros usuários de diferentes localidades.

As comunidades virtuais, ou comunidades online como preferimos chamar, são um fenômeno possibilitado pela web 2.0 que, inicialmente, eram constituídas por pessoas com interesses comuns, que se encontravam via chats ou fóruns de discussões, e desenvolviam atividades conjuntamente. Com o surgimento de softwares sociais como Orkut e, posteriormente, o Facebook, as comunidades online constituíram-se em um tipo de organização social que passou a despertar interesses comerciais, a provocar discussões sobre cultura e, também, preocupações políticas.

Atualmente, as mídias sociais fazem parte de muitas atividades que desenvolvemos. Muitas pessoas possuem perfis em um ou mais softwares sociais acessados via computadores

\footnotetext{
${ }^{1}$ Softwares sociais são programas instalados e executados em servidores e que dão suporte à comunicação de usuários de uma rede social, por exemplo, o Facebook e o Youtube. A rede social é entendida "[...] como um conjunto de dois elementos: atores (pessoas, instituições ou grupos - são os nós da rede) e suas conexões. Essas conexões chamadas laços sociais, são compostas por relações sociais, as quais, por sua vez, são constituídas de interações sociais" (BARANAUSKAS; MARTINS; VALENTE, 2013, p. 26).
} 
pessoais ou por meio de dispositivos móveis. No que toca às comunidades de professores de Matemática, a nova organização decorrente do uso de mídias sociais permite que esses profissionais se organizem em comunidades online nas quais é possível: participar de debates e discussões a respeito de temas da profissão; compartilhar produções com outros colegas; se envolver em produções coletivas e colaborativas; resolver problemas conjuntamente por meio da participação de grupos de interesse.

É nessa perspectiva que, a partir de 2012, passamos a desenvolver algumas iniciativas, utilizando mídias sociais online, e o resultado foi o desenvolvimento de espaços em que professores e/ou futuros professores de Matemática pudessem se envolver em processos formativos por meio da participação em comunidades online. Nossa atuação se centrou na formação de professores quanto à utilização do software GeoGebra e, atualmente, contamos com uma estrutura tecnológica composta por diferentes recursos de mídias sociais:

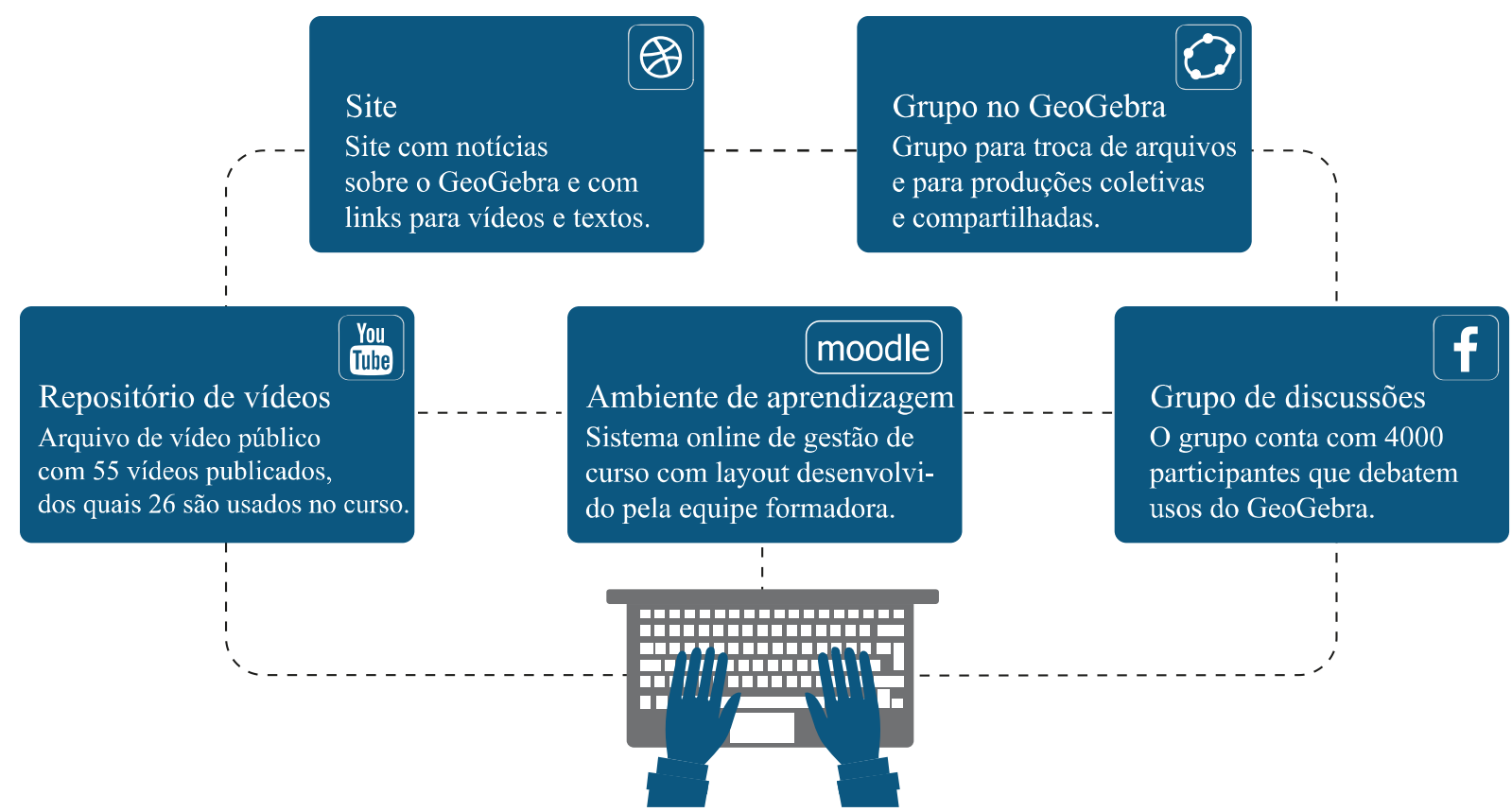

Figura 1 - Estrutura tecnológica utilizada para formação de professores

Fonte: elaborada pelos autores a partir da edição de arquivos vetoriais obtidos em http://www.freepik.com.

Cada uma dessas plataformas - site, ambiente de aprendizagem online, canal de vídeos no Youtube, grupo de discussão no Facebook, grupo no GeoGebra Tube - cumpre certa função dentro da estrutura maior, organizada para a promoção de um curso de formação de professores quanto à utilização do GeoGebra. Nossa intenção foi construir uma interface social em que professores se relacionassem com colegas de profissão e pudessem produzir e se produzir colaborativamente.

$\mathrm{Na}$ próxima seção deste texto abordamos o Curso de GeoGebra e alguns dos pressupostos de formação adotados pelo grupo de trabalho. 


\section{Curso de GeoGebra}

O Curso de GeoGebra corresponde à principal ação desenvolvida na estrutura tecnológica que apresentamos na seção anterior deste texto. Nossas ações formativas têm, como público alvo, estudantes de graduação em Matemática, estudantes de pós-graduação Lato ou Stricto Sensu em Matemática, ou Ensino de Matemática ou Educação Matemática e professores de Matemática de todos os níveis de ensino. Durante a escrita deste texto, realizava-se a décima primeira edição, envolvendo uma equipe formada por 80 profissionais voluntários de várias instituições e estados brasileiros. A Tabela 1 traz informações estatísticas sobre as edições do curso.

Tabela 1 - Curso de GeoGebra: dados de edições realizadas

\begin{tabular}{clccccc}
\hline Edição & Instituição promotora & Início & Término & Inscritos & Professores & Moderadores \\
\hline 1 & UNESP & 15 -jul-12 & 15 -out-12 & 12 & 2 & 1 \\
2 & UNESP & 25 -nov-12 & 9 -mar-13 & 180 & 2 & 2 \\
3 & UFMS & 7 -mai-13 & 29 -jun-13 & 106 & 2 & 2 \\
4 & UFSJ & 4 -ago-13 & 30 -set-13 & 52 & 2 & 3 \\
5 & UFMT/UNIPAMPA & 6-out-13 & 30 -nov-13 & 112 & 2 & 12 \\
6 & UNESPAR & 20 -abr-14 & 28 -jun-14 & 250 & 2 & 34 \\
7 & UNESPAR & 24 -ago-14 & 18 -out-14 & 480 & 2 & 3 \\
8 & UNESPAR & 14 -set-15 & 27 -nov-15 & 330 & 2 & 60 \\
9 & UNESPAR & 09 -mar-16 & 30 -abr-16 & 350 & 2 & 70 \\
10 & UNESPAR & 06-jun-16 & 23 -ago-16 & 370 & 2 & 78 \\
11 & UNESPAR & 05 -out-16 & 23 -nov-16 & 385 & 2 & 2 \\
\hline
\end{tabular}

Fonte: Relatórios produzidos pela equipe organizadora de cada edição do Curso de GeoGebra

O objetivo do curso é possibilitar a produção de conhecimentos sobre o software e fomentar discussões, tematizando a educação matemática ${ }^{2}$. Nessa perspectiva, a equipe de formadores desenvolve o curso como uma comunidade online organizada em fóruns de discussões. Comunidade que envolve cursistas (como nos referimos aos professores em formação) e formadores.

A oitava edição do curso, fonte de dados desta pesquisa, foi realizada em dez módulos e contemplou os seguintes tópicos de estudo (Quadro 1):

\footnotetext{
${ }^{2}$ Educação matemática escrita em minúsculo faz referência ao trabalho realizado por professores de Matemática com vista ao ensino e a aprendizagem de Matemática.
} 


\begin{tabular}{|c|c|}
\hline Módulo & Tópicos \\
\hline 1 & $\begin{array}{l}\text { - Instalação e interface do GeoGebra } \\
\text { - Estudos de linhas retas }\end{array}$ \\
\hline 2 & $\begin{array}{l}\text { - Perpendicular, paralela, bissetriz, mediatriz e mediana } \\
\text { - Propriedades de objetos }\end{array}$ \\
\hline 3 & $\begin{array}{l}\text { - Polígonos } \\
\text { - Isometrias }\end{array}$ \\
\hline 4 & • Funções \\
\hline 5 & $\begin{array}{l}\text { - Comandos } \\
\text { - Comando sequência }\end{array}$ \\
\hline 6 & $\begin{array}{l}\text { - Janela de Visualização 3D } \\
\text { - Prisma e Pirâmide } \\
\text { - Cilindro e Cone }\end{array}$ \\
\hline 7 & $\begin{array}{l}\text { - Círculos, arcos e setores } \\
\text { - Parábola, elipse e hipérbole }\end{array}$ \\
\hline 8 & $\begin{array}{l}\text { - Planilha } \\
\text { - Lugar Geométrico }\end{array}$ \\
\hline 9 & $\begin{array}{l}\text { - Trigonometria } \\
\text { - Construção de novas ferramentas no GeoGebra }\end{array}$ \\
\hline 10 & $\begin{array}{l}\text { - Movimentos em três dimensões } \\
\text { - Poliedros de Platão } \\
\text { - Construção de um jogo no GeoGebra }\end{array}$ \\
\hline
\end{tabular}

Quadro 1 - Tópicos de estudo da $8^{\text {a }}$ edição do Curso de GeoGebra Fonte: $8^{a}$ edição do Curso de GeoGebra

Na dinâmica proposta no curso, em cada módulo, o cursista é orientado a assistir uma ou mais videoaulas ${ }^{3}$ e a consultar os materiais textuais complementares, ambos produzidos pela equipe de formadores e disponibilizados no ambiente de aprendizagem online. Em seguida, deve realizar uma produção que envolve duas dimensões de trabalho: uma individual e outra coletiva.

A dimensão individual compreende a etapa do trabalho em que o cursista pode mobilizar conhecimentos oriundos de sua formação (graduação, pós-graduação) e de sua prática profissional. O cursista pode aliar esses conhecimentos aos supostamente produzidos sobre o software ao acessar as videoaulas e os materiais textuais, e construir um arquivo no GeoGebra. Em seguida, ainda na dimensão individual, o cursista deve escrever um texto sobre sua construção, explicitando os recursos do software que empregou, os objetivos educacionais do arquivo construído ou os modos de explorá-lo em sala de aula de Matemática. Essa produção deve ser compartilhada com os demais cursistas e com os formadores, por meio da criação de um novo tópico no fórum do respectivo módulo, ou seja, uma postagem com o arquivo e seu texto que correspondem à primeira parte da tarefa que compõe cada módulo.

\footnotetext{
${ }^{3}$ Vídeos gravados a partir da captura de tela do computador enquanto são realizadas demonstrações de modos deuso do software GeoGebra. Disponíveis em: 〈http://ogeogebra.com.br〉. Acesso em: 01 jun. 2016.
} 
Na dimensão coletiva, cada cursista deve acessar o que foi publicado no fórum por, no mínimo, dois outros cursistas e interagir com eles. As orientações para essa interação, geralmente, são apresentadas no enunciado da tarefa e podem compreender: comentar as publicações dos colegas com sugestões de alterações; perguntar sobre procedimentos utilizados na construção do arquivo ou sobre como utilizá-lo em uma aula de Matemática; fazer download do arquivo postado, realizar modificações e postá-lo novamente no mesmo tópico.

Na Figura 2 são exibidos os tópicos de estudo do Módulo 1, em forma de hiperlinks, das videoaulas, do material escrito (material de apoio 1) e do enunciado da Tarefa 1. É apresentada, ainda, uma expansão da janela da Tarefa 1 em que é exibido o enunciado dessa tarefa.

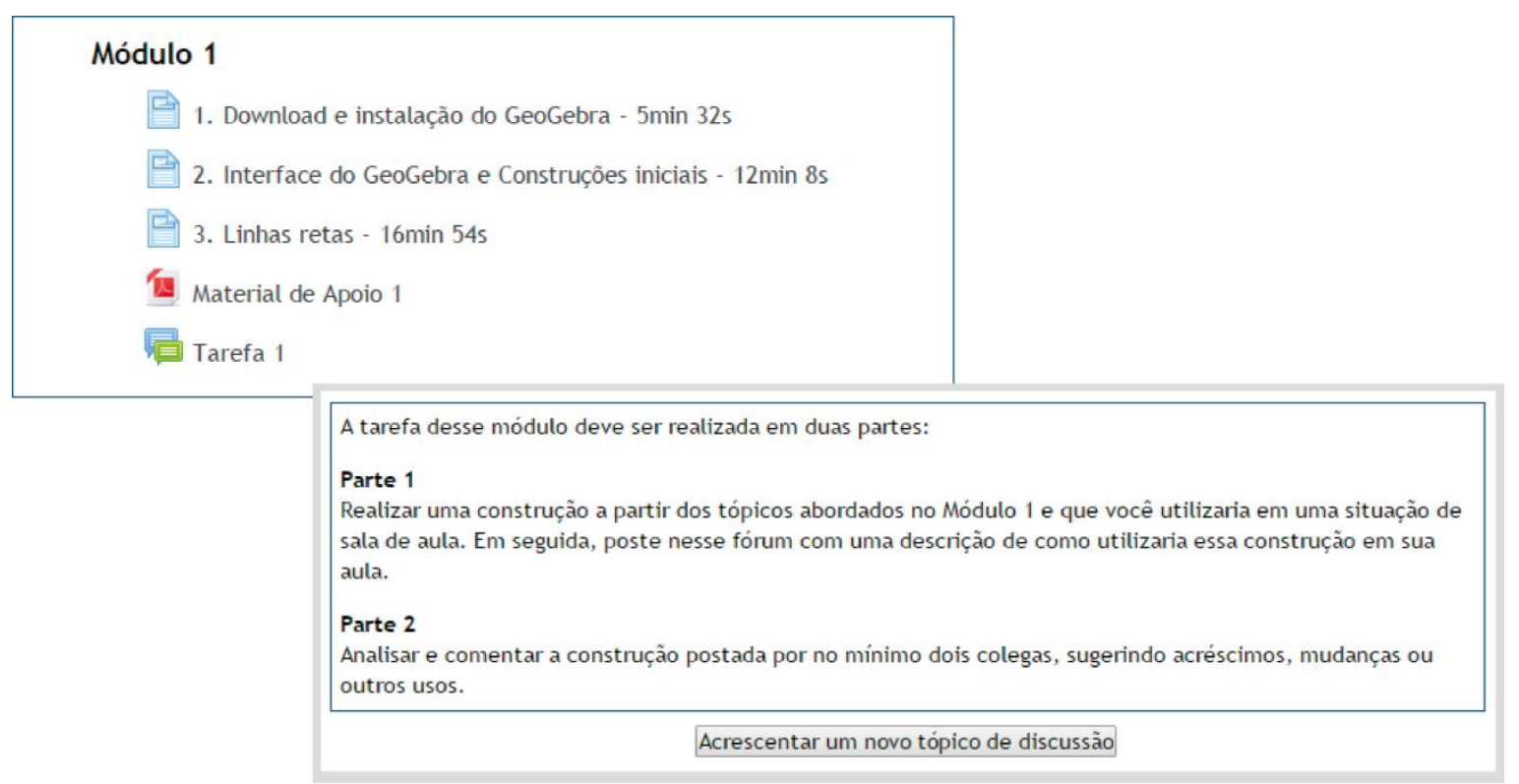

Figura 2 - Materiais e Tarefa do Módulo 1 da $8^{a}$ edição do Curso de GeoGebra Fonte: $8^{\mathrm{a}}$ edição do Curso de GeoGebra

Tanto os materiais produzidos pela equipe de formadores (videoaulas e materiais textuais) como os enunciados das tarefas foram elaborados com base em pressupostos para formação de professores fundamentados no Modelo dos Campos Semânticos (MCS) de Lins (1999, 2004, 2012), quais sejam: interação, diferença, estranhamento, descentramento e colaboração. Remetemos o leitor para Dantas (2015) em que esses pressupostos são abordados em detalhes.

Entre os pressupostos apontados anteriormente, consideramos relevante retomar, neste texto, o que entendemos por interação e que é baseado em algumas noções do MCS. E, para discorrer sobre esse tema, consideramos necessário discutir duas noções: autor e leitor. 
Por exemplo, enquanto escrevemos este texto, estamos falando para um interlocutor que instituímos. Nos termos do MCS, esse é um ser cognitivo (não biológico) que diria as mesmas coisas que dizemos e com a autoridade que imaginamos. Ele é chamado de um leitor e é instituído por nós, os autores. Por outro lado, o leitor, no momento de sua leitura, institui ou instaura alguém que escreveu o que lê, ou seja, institui um autor.

Quem produz uma enunciação é o autor. $\underline{\mathrm{O}}$ autor fala sempre na direção de $\underline{\text { um }}$ leitor, que é constituído (produzido, instaurado, instalado, introduzido) pelo o autor. Quem produz significado para um resíduo de enunciação é o leitor. $\underline{\mathrm{O}}$ leitor sempre fala na direção de um autor, que é constituído (produzido, instaurado, instalado, introduzido) pelo o leitor.

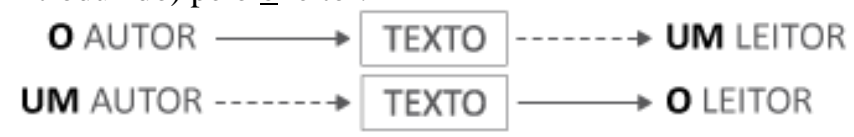

(LINS, 2012, p. 14, grifos e imagem do original).

No MCS, tanto um autor como um leitor são chamados de direções de interlocução e referidos, simplesmente, como interlocutores, aqueles que delimitam formas de produção de significado. Ao instituir um matemático como o interlocutor para quem falamos, dizemos de coisas que são e que não são legítimas de serem ditas. Legítimas, pois seriam possíveis a partir do modo de produção de significados do matemático.

Em processos dialógicos em que dois ou mais sujeitos estão assumindo, alternadamente, papéis de o autor e de o leitor, há o que chamamos de interação. Essa noção permite afirmar que, em uma conversa entre duas pessoas, uma não fala em direção a outra, mas para interlocutores instituídos por ambas. Segundo Lins (2012, p. 24), a comunicação corresponde a "dois sujeitos cognitivos falando na direção de um mesmo interlocutor".

Por essa afirmação é possível admitir que duas pessoas podem ou não falar em uma mesma direção. Quando não falam em uma mesma direção, não compartilham interlocutores. Elas não deixam de estar interagindo, mas podemos questionar sobre a possibilidade de estarem se comunicando.

Quando as direções são as mesmas, dizemos que estão compartilhando interlocutores ou dizemos que estão em uma interação produtiva. Esse é o tipo de interação que a equipe formadora tem como objetivo nas ações que desenvolve na comunidade online do Curso de GeoGebra.

O trecho de diálogo que segue (Figura 3), foi retirado de um dos fóruns da $8^{\mathrm{a}}$ edição do curso e, segundo nossa leitura, é um caso exemplar de interação produtiva, pois os cursistas interagem e, como resultado, produzem novos conhecimentos. 


POLIEDROS DE PLATÃO
POR SÔNIA - QUARTA, 28 OUTUBRO 2015, 20:43
Olá colegas! Como o enunciado da tarefa diz que posso compartilhar uma dúvida, farei isso em minha postagem.
Tenho várias na verdade! Tentei fazer o dodecaedro conforme explicado no vídeo desse módulo, mas não consegui.
Gostaria de usar o GeoGebra para preparar uma aula sobre poliedros de Platão. Alguém pode me ajudar?

\begin{tabular}{|l|l|}
\hline RE: POLIEDROS DE PLATÃO \\
POR CHARLES - QUINTA, 29 OUTUBRO 2015, 08:39 \\
Quais poliedros você deseja fazer Sõnia?
\end{tabular}

Charles, eu gostaria de construir todos, cada um em um arquivo.

RE: POLIEDROS DE PLATÃO
POR CHARLES - DOMINGO, 1 NOVEMBRO 2015, 14:12
$\begin{aligned} & \text { Sônia, para construir um poliedro de platão você pode digitar o comando e alguns parâmetros. Por } \\ & \text { exemplo, para construir o hexaedro, basta digitar Cubo [ <Ponto>, <Ponto> ]. Substitua os termos } \\ & \text { <Ponto> por coordenadas de pontos em três dimensões. Veja o arquivo que construí de um cubo } \\ & \text { anexo. Tente fazer os outros. }\end{aligned}$

RE: POLIEDROS DE PLATÃO
ORÓál Muito obrigada pela dica. Vi que tem comandos para construir cada um deles!
Consegui fazer todos usando os comandos.

Figura 3 - Trecho de um diálogo entre Sônia e Charles em um fórum Fonte: $8^{a}$ edição do Curso de GeoGebra

Além da interação produtiva, a equipe de formação almeja que a comunidade online do Curso de GeoGebra, na dimensão coletiva das tarefas, desenvolva uma forma de trabalho em que se manifeste a colaboração.

E a colaboração é pensada a partir da noção de atividade de Leontiev (1978). Para esse autor, uma atividade é composta por três elementos estruturais: necessidade, objeto e motivo. A necessidade é o princípio da atividade, é o que "dirige e regula a atividade do sujeito" (ASBAHR, 2005, p. 29). Quando um objeto corresponde a uma necessidade, segundo Leontiev (1978), é possível afirmar que a atividade tem um motivo.

A tarefa proposta via enunciado torna-se uma atividade para o cursista quando, durante a realização da dimensão individual do trabalho, suas ações têm como motivo atender a uma demanda apontada pela atividade de ensino proposta pelos formadores. No segundo 
momento, durante a realização do trabalho na dimensão coletiva, os motivos individuais, ou seja, o que leva um cursista a constituir um arquivo e postar no fórum, passam a ser motivos compartilhados pelos integrantes do grupo, que interagem com ele em sua postagem quando fazem inserções na tentativa de compartilharem interlocutores. A esse trabalho conjunto, em que os cursistas em processos de interação compartilham interlocutores e motivos, chamamos de interação colaborativa.

Essa é a interação que nos interessa desenvolver na comunidade online do Curso de GeoGebra, pois o grupo de cursistas formado por pessoas com necessidades próximas, quando se envolve em interações produtivas, pode construir um ambiente propício a compartilhar dúvidas, modos de produção de significados, legitimidades, materiais para a educação matemática e, sobretudo, pode produzir novos conhecimentos.

\section{Dados e método}

Neste texto apresentamos a análise de alguns resultados observados por nós nas interações ocorridas nos fóruns da $8^{\mathrm{a}}$ edição do Curso de GeoGebra. É importante salientar que nessa edição havia 330 cursistas inscritos e uma equipe de formação constituída por 40 profissionais. Os cursistas foram divididos em cinco grupos, para que os fóruns tivessem um volume de postagens que não causasse uma demanda de acesso que um cursista não daria conta mesmo se dispondo a isso. Na prática, isso significa que havia cinco comunidades online com 65 cursistas cada e com oito professores, ou seja, cinco grupos com 73 integrantes que não tinham acesso aos integrantes e às produções dos outros grupos.

Tomamos, para este estudo, um dos grupos escolhido por sorteio entre os cinco existentes. Ao longo de dez módulos do curso, os integrantes do grupo, tomado para estudo, fizeram 456 postagens em dez fóruns. Conforme já mencionado, esses fóruns são espaços online em que todos os integrantes de um grupo, cursistas e formadores, interagem motivados pelas produções publicadas.

Cada tópico criado por um cursista no fórum é referido, neste texto, como uma postagem. A partir de uma postagem, os demais cursistas escrevem questionamentos, observações, sugestões, entre outros, que chamamos de inserções. Chamamos, também, de inserções as respostas dadas pelo autor da postagem às inserções dos colegas. No grupo tomado para estudo, uma postagem teve no máximo 27 inserções e, em média, sete. Tendo 
isso em vista, examinamos todas as postagens com sete ou mais inserções, em um total de 70 tópicos no fórum.

Consideramos importante ressaltar, também, que cada cursista cria apenas um tópico em cada fórum, e posta um arquivo e um texto que aborda seu construto. Porém, ele pode interagir em várias postagens. Geralmente, nos enunciados das tarefas, ele é orientado a interagir com dois outros cursistas, mas acaba interagindo com mais colegas. Neste texto, argumentamos mais especificamente sobre esse fenômeno mais à frente.

As relações estabelecidas entre os cursistas, por meio de diálogos nos tópicos dos fóruns, criam vínculos entre eles. Assim, quando um cursista comenta a tarefa de um colega, geralmente o que recebeu o comentário visita a postagem do primeiro e, também, interage com ele. Dessa relação surge a noção de uma rede no interior de cada grupo, em que os cursistas são os nós e as relações entre eles são os laços.

A Figura 4 corresponde à representação gráfica do mapeamento da rede ${ }^{4}$ formada pelos cursistas e professores do grupo tomado para estudo durante o módulo 1 do curso. Cada participante do grupo é representado por um círculo e o gráfico é gerado a partir das interações nos fóruns, ou seja, quanto mais um participante faz inserções ou recebe inserções em suas postagens, maior é o círculo que o representa.

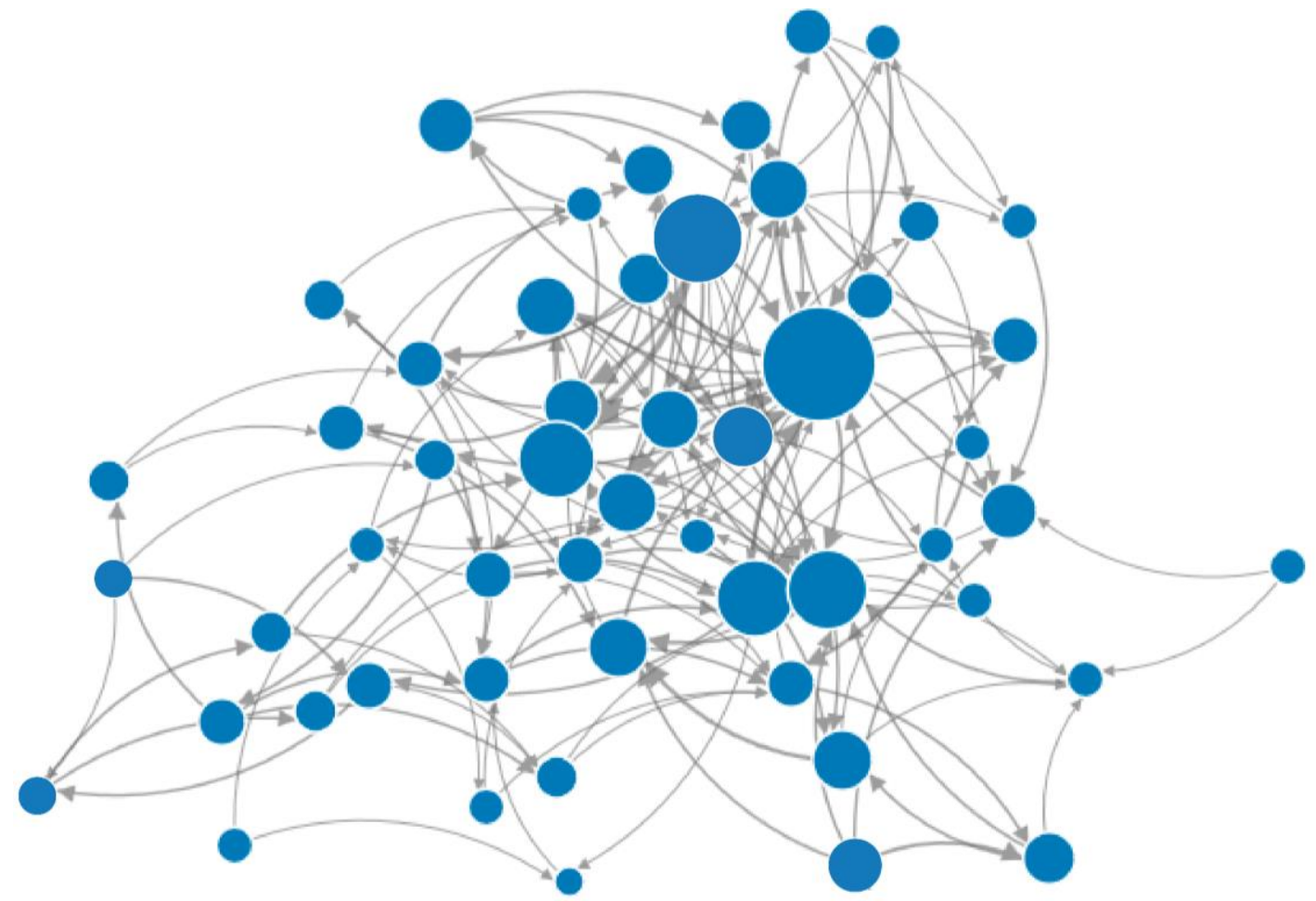

\footnotetext{
${ }^{4}$ As ações dos cursistas são registradas automaticamente em um banco de dados do ambiente de aprendizagem online $(\log s)$, e, por meio de recursos do sistema, é possível gerar mapas para descrever e estudar as relações estabelecidas no interior dos grupos. Esse gráfico foi gerado, utilizando o FórumGraph, um módulo adicional instalado pela equipe no Moodle.
} 
Figura 4 - Representação gráfica de um mapeamento da rede formada pelas relações entre os cursistas no Módulo 1 da $8^{\text {a }}$ edição do Curso de GeoGebra

Fonte: $8^{\mathrm{a}}$ edição do Curso de GeoGebra

Neste estudo em que descrevemos algumas características da interação colaborativa desenvolvida nos espaços de interação, apresentamos três postagens com as respectivas inserções de outros cursistas. Entre uma inserção e outra, apresentamos argumentos para destacar o objeto de estudo desta pesquisa.

\subsection{Postagem 1}

Uma das propostas da equipe formadora do Curso de GeoGebra é fomentar o acesso a um recurso tecnológico e criar oportunidades para que o cursista se encoraje a incorporá-lo nas atividades que desenvolve. Para isso, são propostas, por meio de enunciados de tarefas, situações de trabalho diversas: produção de arquivos para sala de aula, resolução e investigação de problemas em que a utilização do GeoGebra seja necessária, utilização do software para produção de imagens e jogos sem, necessariamente, ter fins didáticos, entre outros.

Nesse contexto, o cursista é chamado à ação desde o primeiro módulo. Ele é envolvido em atividades que visam levá-lo a desenvolver um repertório de experiências com o GeoGebra, atento a suas possibilidades e a seus limites.

A dimensão coletiva das tarefas permite que o cursista se insira em uma comunidade de usuários que desenvolve métodos próprios de produção com o GeoGebra, e que também questiona esses métodos. Esse fenômeno foi observado na postagem de Sidney à tarefa do Módulo 1, que tinha o seguinte enunciado (Figura 5):

TAREFA 1

A tarefa desse módulo deve ser realizada em duas partes:

Parte 1

Realizar uma construção a partir dos tópicos abordados no Módulo 1 e que você utilizaria em uma situação de sala de aula. Em seguida, poste nesse fórum com uma descrição de como utilizaria essa construção em sua aula.

Parte 2

Analisar e comentar a construção postada por no mínimo dois colegas, sugerindo acréscimos, mudanças ou outros usos.

Figura 5 - Enunciado da Tarefa do Módulo 1 da $8^{\text {a }}$ edição do Curso de GeoGebra Fonte: $8^{\mathrm{a}}$ edição do Curso de GeoGebra 
A partir de sua produção de significados para o enunciado, Sidney construiu um arquivo no GeoGebra e postou no fórum, acompanhado de uma descrição dos passos que realizou. $\mathrm{O}$ arquivo postado por ele tinha o seguinte aspecto visual (Figura 6):

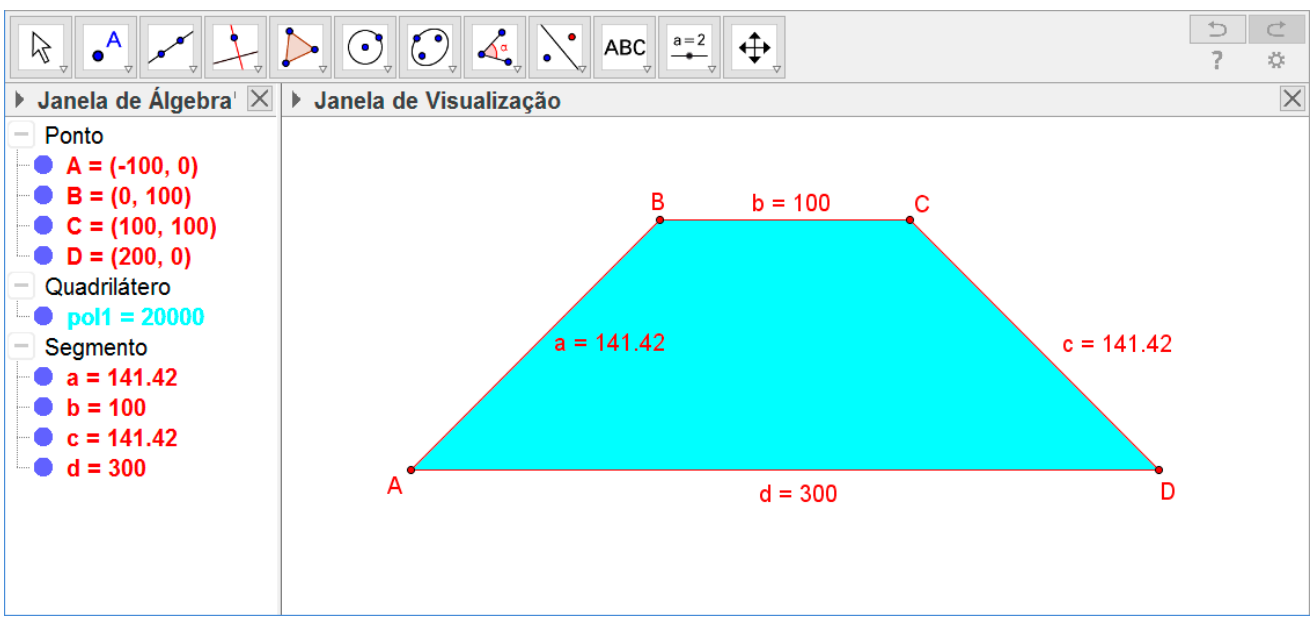

Figura 6 - Tela do arquivo anexado por Sidney em sua postagem na Tarefa do Módulo 1

Fonte: $8^{\mathrm{a}}$ edição do Curso de GeoGebra

Como se tratava do primeiro módulo do curso, Sidney pareceu utilizar os conhecimentos que desenvolvera até ali para construir um trapézio isósceles. Suas afirmações diziam respeito a como utilizar o GeoGebra para realizar aquela construção.

TRAPÉZIO ISÓSCELES
POR SIDNEY- QUINTA, 17 SETEMBRO 2015, 17:33
Passos para a construção:
1- Clicando com o botão direito sobre a janela de visualização, coloquei a malha no fundo da tela para que ficasse
mais exata a marcação dos pontos.
2- Novamente, cliquei com o botão direito sobre a referida janela e ocultei os eixos x e y.
3- Em seguida, clicando no ícone polígono, construí um trapézio isósceles.
4- Para que os segmentos a e c ficassem com o mesmo tamanho, cliquei sobre o ícone mover, sobre o ponto C,
arrastei-o observando a medida dos segmentos na janela de álgebra que modificavam à medida que o ponto era
arrastado. Parei de arrastá-lo quando a=c.
5- Para centralizar a figura, cliquei sobre o ícone mover janela de visualização(12o ícone da barra de ferramentas) e,
em seguida, cliquei sobre o ícone mover ponto ( 10 ícone ) para que os pontos ( A,B,C,D) e os segmentos (a,b,c,d)
ficassem visíveis do lado externo da figura.
6- Cliquei com o botão direito sobre a Janela de Visualização e na aba propriedades, fui até a janela preferências,
cliquei no ícone cor, passei o mouse sobre o tabuleiro de cores e selecionei a cor Cíano 0,255,255.
7- Arrastando a régua na caixa transparência, fixei-a no ponto 50 .
8- Para diferenciar as cores dos pontos e segmentos da cor da figura, selecionei cada um e selecionei a cor
vermelha.
9- Em seguida, cliquei com o botão direito sobre a janela de visualização e na aba malha, cliquei para retirá-la do
fundo da tela.
10- Finalmente clicando em arquivo, fui até gravar como para salvar o documento em uma pasta especifica para
possíveis modificações futuras e postagem do arquivo construído.

\section{Figura 7 - Descrição de Sidney sobre sua construção}

Fonte: $8^{\mathrm{a}}$ edição do Curso de GeoGebra

Convém ressaltar que, até aquele momento do curso, foram abordadas a instalação e interface do GeoGebra e como construir pontos, retas e polígonos. Assim, sendo um cursista 
iniciante, Sidney utilizou de conhecimentos supostamente construídos até aquele momento para realizar uma construção que julgava atender a proposta do enunciado da tarefa.

A primeira inserção em sua postagem foi de Alice, que analisou a forma como a construção foi realizada. Lembramos que, para isso, ela teve que salvar, em seu computador, uma cópia do arquivo postado por Sidney e abri-lo, utilizando o GeoGebra.

$\mathrm{Na}$ inserção de Alice, segundo nossa leitura, há indícios de que ela teve atenção ao passo a passo da construção descrito pelo colega. Isso permitiu que ela tivesse acesso a diversos métodos de utilização do programa. Por um lado, os materiais do curso (vídeos e textos) apresentam perspectivas de uso de alguns especialistas no GeoGebra (equipe formadora), mas esses modos não são únicos e tampouco hegemônicos.

A equipe formadora compreende que as postagens dos cursistas nos fóruns integram e complementam os materiais do curso, permitindo à comunidade envolvida uma formação ampla quanto ao repertório de experiências com o programa.

Além de ter atenção à descrição feita pelo colega, Alice sugeriu uma possibilidade de utilização do arquivo em uma aula de Matemática, o que parece ter sido bem aceito por Sidney.

\begin{tabular}{|c|c|}
\hline & $\begin{array}{l}\text { RE: TRAPÉZIO ISÓSCELES } \\
\text { POR ALICE- QUINTA, } 17 \text { SETEMBRO 2015, 23:07 }\end{array}$ \\
\hline & $\begin{array}{l}\text { Ola Sidney, adorei sua construção, vi que você utilizou varias ferramentas do Geogebra. O trapézio é uma } \\
\text { figura com muitas particularidades e com certeza o uso do Geogebra facilita a percepção dos alunos quanto a }\end{array}$ \\
\hline Alice & $\begin{array}{l}\text { isso. Muito bem explicado, o passo a passo de sua construção está perfeito no meu ponto de vista! Sugestão: } \\
\text { utilize-o para demonstrar o perímetro e a área da figura; com certeza seus alunos ficarão maravilhados. } \\
\text { Parabéns! Abraços, Alice. }\end{array}$ \\
\hline
\end{tabular}

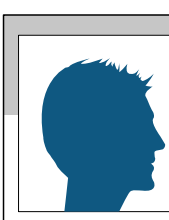

Sidney

RE: TRAPÉZIO ISÓSCELES

POR SIDNEY- SEGUNDA, 21 SETEMBRO 2015, 17:40

Olá Alice! Obrigado por suas observações e colocações! Eu trabalho o perímetro e área nas construções com os alunos em sala de aula, mas não os coloquei aqui na postagem porque me limitei apenas à construção. Mas vou refazer a atividade e colocar estes passos também. Obrigado pela orientação. Abraços

Figura 8 - Inserção de Alice e reposta de Sidney

Fonte: $8^{\mathrm{a}}$ edição do Curso de GeoGebra

Alice, por certo, estava atenta às orientações presentes nas partes 1 e 2 do enunciado da tarefa. Na parte 1 havia a indicação para o cursista construir um arquivo para utilizar em uma sala de aula e descrever possibilidades de uso. Na parte 2, o comando era que analisasse o arquivo postado por outros cursistas e sugerisse alterações ou acréscimos.

A postagem de Sidney, seguida das inserções de seus colegas (Alice, Mário, Pablo e Ane) aparece no fórum conforme a sequência apresentada na Figura 9. 
Quando uma inserção é escrita em resposta a outra, no fórum, ela é posicionada com recuo à esquerda maior que da anterior e logo em seguida da primeira.

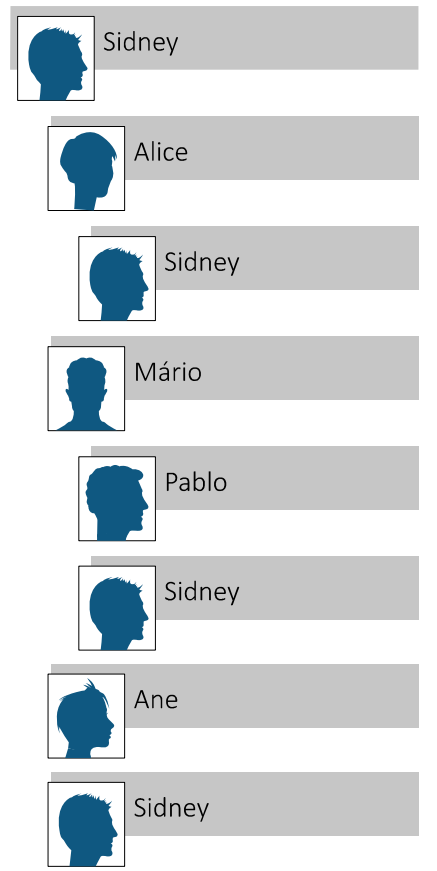

Figura 9 - Organização por recuos das inserções nos fóruns

Fonte: elaborado pelos autores a partir de dados da $8^{\mathrm{a}}$ edição do Curso de GeoGebra

Essa organização não obedece, necessariamente, uma cronologia das inserções.

Sidney realizou sua postagem no primeiro dia de vigência do Módulo 1. Em seguida, Alice, Mário, Pablo e Ane fizeram inserções na forma de comentários. O cronograma a seguir (Figura 10) apresenta o fluxo das postagens.

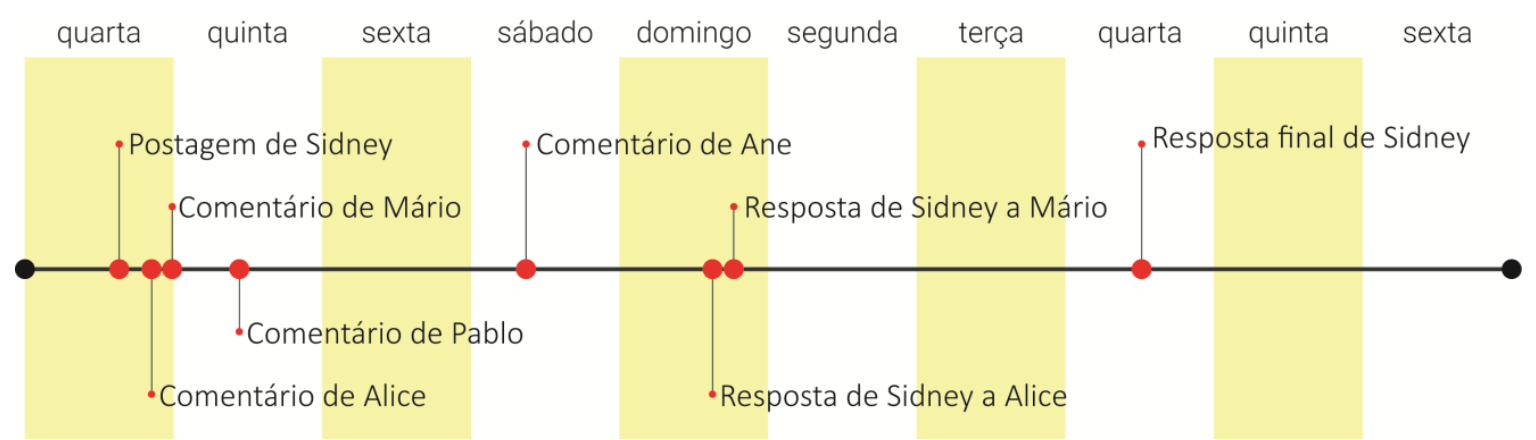

Figura 10 - Cronograma das inserções realizadas na postagem de Sidney Fonte: $8^{\mathrm{a}}$ edição do Curso de GeoGebra

Assim, a organização recuada das inserções no fórum apresenta as inserções e as respectivas respostas, em uma certa ordem, que possibilita compreender um comentário, a resposta dada a tal comentário, de forma a privilegiar o diálogo em torno de um assunto. Porém, essa organização não privilegia compreender em que tempo foi realizada cada inserção pelos interagentes no fórum sem que tenhamos atenção às datas e horários que foram conservados nos recortes de postagens que apresentamos neste texto. 
Chamamos atenção à questão da cronologia das inserções, pois o comentário de Mário mostra que, além de estar atento à postagem de Sidney, se preocupou em analisar o que Alice escreveu. E, no momento que Mário fez sua inserção, Sidney ainda não dialogara com Alice.

Mário também compreendeu como legítimas as colocações de Alice sobre a necessidade de uma proposta de uso do arquivo em sala de aula. Ele ressaltou que os passos da construção estavam detalhados. O início de seus comentários diz respeito a duas direções de interlocução: ao método de construção e à utilização didática do arquivo. Porém, ele chamou atenção à outra possibilidade: os conhecimentos matemáticos construídos quando se utiliza softwares de geometria dinâmica.

Como o GeoGebra permite construir uma figura e, em seguida, realizar modificações em coordenadas, medidas, entre outros atributos da construção, Mário sugeriu que a construção fosse realizada de tal modo que o trapézio isósceles não perdesse certas propriedades quando o usuário do arquivo realizasse movimentos nos elementos que o compõem: lados e vértices.

RE: TRAPÉZIO ISÓSCELES
POR MÁRIO- QUINTA, 17 SETEMBRO 2015, 23:46
Olá Sidney. Sua descrição dos passos utilizados na construção está bem detalhada e muito bem feita.
Parabéns! Gostaria de provocar duas questões:
1. A primeira é referente à ideia da tarefa. Senti falta de uma proposta de como trabalhar essa construção em
sala de aula. Alice já deu algumas sugestões.
2. A segunda é referente a uma ideia muito importante quando discutimos geometria dinâmica: SER e ESTAR.
O quadrilátero que você construiu ESTÁ um trapézio isósceles, mas ele não É um trapézio isósceles. Uma figura
É alguma coisa quando, mesmo depois de manipulada, ela continua SENDO aquela coisa. Isso significa que
temos que nos preocupar, ao longo da construção, em garantir que as características essenciais da figura serão
mantidas, mesmo depois de manipulações. Como seria a construção de uma figura que É um trapézio
isósceles? Penso que logo logo teremos acesso a ferramentas que poderão nos ajudar nessa construção.
Bons estudos para nós!




RE: TRAPÉZIO ISÓSCELES
POR ANE - DOMINGO, 20 SETEMBRO 2015, 11:33
Olá Sidney! Gostei de sua atividade, porém se alguém deslocar algum vértice, não terá mais um trapézio
isósceles, e sim um quadrilátero qualquer.
Eu sugiro que comece a construção com a definição, dois lados paralelos. Utilize retas paralelas e depois de
terminar a construção as esconder.
Abraços. Ane.

Figura 11 - Inserções de Mário, de Pablo e de Ane na postagem de Sidney Fonte: $8^{\mathrm{a}}$ edição do Curso de GeoGebra

Logo após o comentário de Mário, Pablo acessou a postagem de Sidney e concordou com Mário. Ane também questionou o fato de a figura ser deformável, sugerindo que Sidney utilizasse retas paralelas na construção. Contudo, nenhum deles (Mário, Pablo e Ane) escreveu instruções de como realizar a construção de um trapézio isósceles no GeoGebra.

As inserções desses cursistas são provocações que, por certo, levaram Sidney a refletir sobre outra forma de obter um trapézio isósceles. E, passado certo tempo dos comentários, ele apresentou outra construção.

RE: TRAPÉZIO ISÓSCELES
POR SIDNEY - QUINTA, 24 SETEMBRO 2015, 14:57
Olá!
Acatando algumas orientações dos colegas, refiz a figura do trapézio isósceles, proposto no início do
cumprimento da tarefa.
Levei em consideração o fato de como aplicar a atividade em sala de aula. Para isto introduzi a área e o
perímetro da figura. Para isto basta ir até o comando ângulo e descer com o mouse até o terceiro e quarto
subcomando respectivamente. Desta vez a construção da figura foi feita utilizando o comando polígono, e em
seguida descendo até o subcomando polígono regular. Creio que agora a figura pode ser movida tanto pelo
ponto B ou C, e não perderá suas características.
Agradeço a todos que colocaram seus questionamentos. Me fizeram crescer no aprendizado!
Att: Sidney

Figura 12 - Resposta de Sidney acompanhada de nova construção Fonte: $8^{\mathrm{a}}$ edição do Curso de GeoGebra

A nova construção atendeu às sugestões dos cursistas que interagiram com Sidney. Ele obteve um trapézio isósceles que não permite alterar as medidas de seus lados e, além disso, exibe o perímetro e a área.

Para realizar a nova construção (Figura 13), Sidney clicou na ferramenta Ponto e construiu quatro pontos: $\mathrm{A}=(0,0), \mathrm{B}=(6,0), \mathrm{C}=(4,3)$ e $\mathrm{D}=(2,3)$. 


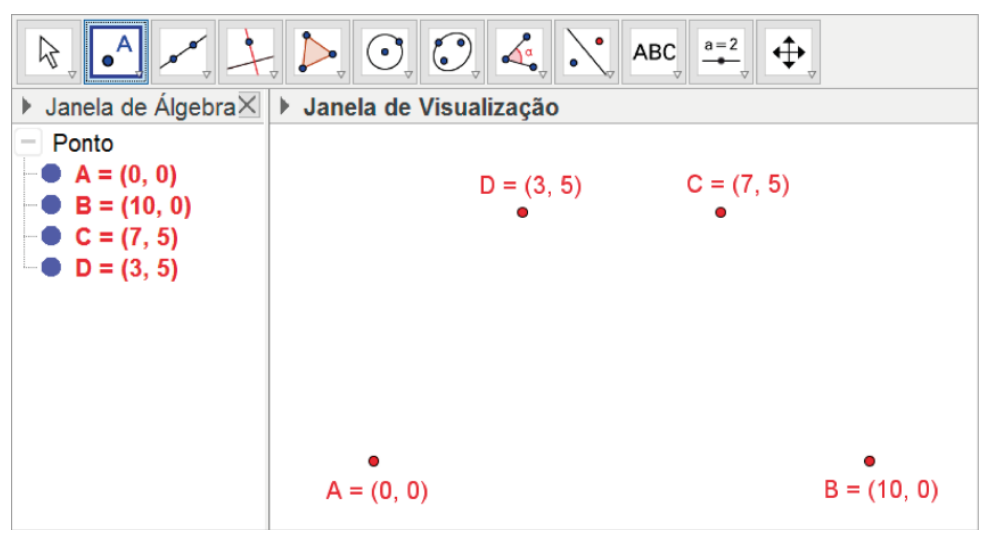

Figura 13 - Passos iniciais da nova construção de Sidney Fonte: $8^{\mathrm{a}}$ edição do Curso de GeoGebra

Em seguida, clicou na ferramenta Polígono Rígido e clicou nos pontos construídos previamente. O GeoGebra retornou um trapézio isósceles, pois as coordenadas dos pontos A, B, C e D foram escolhidas por ele para obter esse resultado. Além disso, a ferramenta Polígono Rígido redefiniu os pontos B, C e D em função do ponto A. O ponto B foi escrito como sobre um círculo de raio fixo, e os pontos C e D como combinações lineares dos pontos A e B.

- $\mathrm{B}=$ Ponto[Círculo[A, 10]]

- $\mathrm{C}=\mathrm{A}+0.7 \operatorname{Vetor}[\mathrm{A}, \mathrm{B}]+0.5 \operatorname{VetorPerpendicular}[\operatorname{Segmento}[\mathrm{A}, \mathrm{B}]]$

- $\mathrm{D}=\mathrm{A}+0.3 \operatorname{Vetor}[\mathrm{A}, \mathrm{B}]+0.5 \operatorname{VetorPerpendicular}[\operatorname{Segmento}[\mathrm{A}, \mathrm{B}]]$

A nova construção de Sidney conta com um elemento interno do GeoGebra: Polígono Rígido. Em outras palavras, foi construído um polígono que não permite que sejam alteradas algumas de suas características, por exemplo o comprimento de seus lados e, consequentemente, seu perímetro. Não é possível, também, alterar sua área. É possível apenas alterar o ponto A, que fixa o polígono, e o ponto $\mathrm{B}$, que controla seu giro em torno do ponto A.

Não podemos afirmar que os colegas que interagiram com Sidney se referiam a essa forma de construção! Eles poderiam estar falando sobre uma construção que possibilitasse alterar vértices do trapézio isósceles, de maneira que ele continuasse isósceles. Nesse caso, sua área e seu perímetro poderiam ser alterados. Porém, a construção seria outra, os conhecimentos matemáticos em jogo não seriam os mesmos, as ferramentas do software poderiam variar. Poderiam ocorrer outras enunciações e outras possibilidades de interações produtivas.

\subsection{Postagem 2}


Os fóruns de cada módulo do Curso de GeoGebra são oportunidades para os participantes colocarem em prática os conhecimentos desenvolvidos por meio dos tópicos de estudo e, também, para realizarem construções de materiais úteis para utilização em suas práticas profissionais. Isso se manifesta no diálogo entre cursistas, que apresentamos nesta seção. A partir da construção da cursista Karina, com vista a explorar o Teorema de Pitágoras em sala de aula, outros colegas fizeram sugestões escritas e, também, acompanhadas de novas versões do arquivo com modificações ou incrementos. A postagem de Karina foi a seguinte:

DEMONSTRAÇÃO DO TEOREMA DE PITÁGORAS POR ÁREAS
POR KARINA - QUARTA, 16 SETEMBRO 2015, 14:44
Atividade: Mostrar a relação de Pitágoras por meio das áreas de quadrados construídos a partir dos lados de um
triângulo retângulo.
$\begin{aligned} & \text { Construi o triângulo retângulo usando a ferramenta "Polígono". Em seguida, sobre cada lado, construí os quadrados } \\ & \text { utilizando a ferramenta "Polígono Regular". } \\ & \text { Na Janela de Álgebra é possível ver o valor da área de cada polígono. } \\ & \text { Atividade inicial para mostrar a Relação de Pitágoras e para os alunos fazerem quando começarem a aprender sobre } \\ & \text { o software GeoGebra. }\end{aligned}$

Figura 14 - Postagem de Karina com arquivo anexo e descrição de sua construção Fonte: $8^{a}$ edição do Curso de GeoGebra

$\mathrm{O}$ arquivo que acompanhou a postagem apresentava o seguinte aspecto visual (Figura 15):

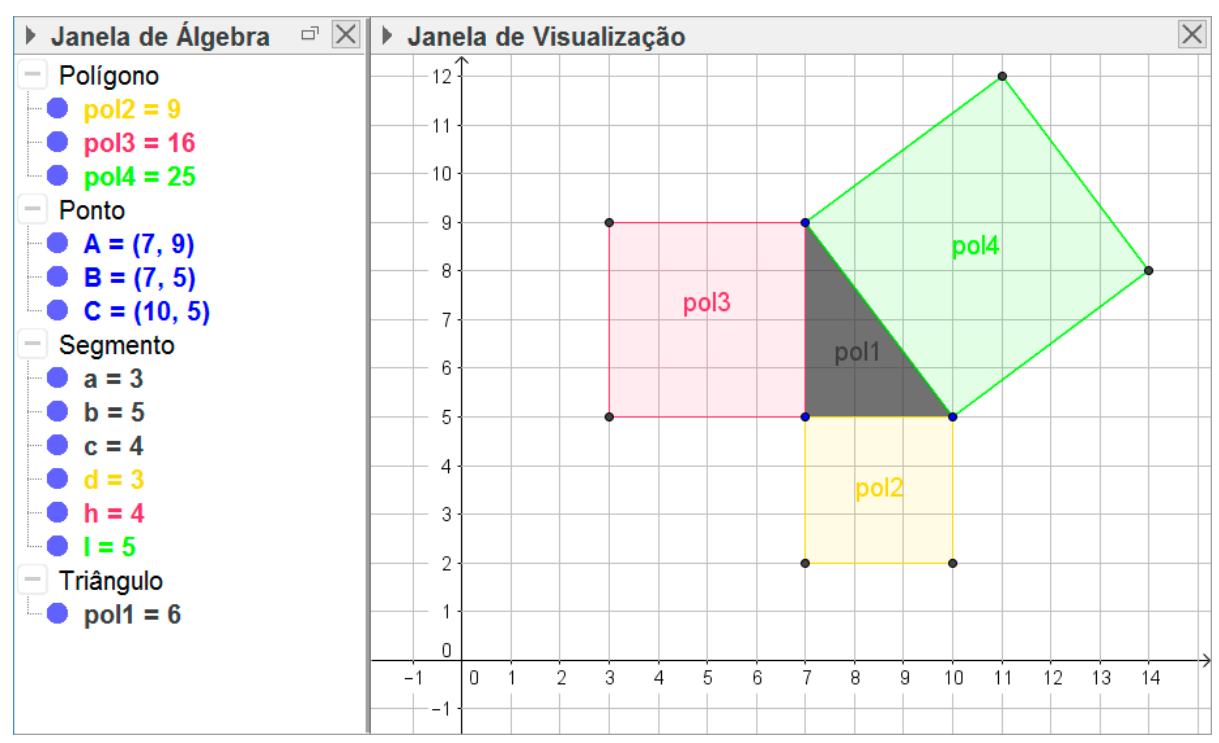

Figura 15 - Arquivo construído por Karina na Tarefa do Módulo 1 Fonte: $8^{\mathrm{a}}$ edição do Curso de GeoGebra

A cursista descreveu, em sua postagem, que é possível identificar na Janela de Álgebra (à esquerda da tela) o valor da área de cada polígono. Esses valores são os seguintes: pol2 = 9, pol3 $=16$ e pol4 $=25$. Valores que são calculados automaticamente pelo GeoGebra. Assim, à medida que o aluno modificasse os vértices do triângulo (pol1), as áreas dos quadrados 
construídos sobre seus lados seriam recalculados pelo software e o professor teria a oportunidade de discutir o Teorema de Pitágoras.

É legítimo afirmar que a ideia é concluir que $\mathrm{a}^{2}+\mathrm{b}^{2}=\mathrm{c}^{2}$, por meio da análise de pol2 + pol3 = pol4. Daí a importância de a cursista ter exibido o plano cartesiano com valores nos eixos $\mathrm{x}$ e $\mathrm{y}$ sendo incrementados em uma unidade e, também, ter exibido a malha quadriculada na Janela de Visualização.

Ao analisar a construção de Karina, percebe-se que há o risco, durante a utilização em sala de aula, de o triângulo deixar de ser retângulo, conforme apresentado na Figura 16. Utilizando o mouse, um aluno pode clicar sobre um dos pontos e deslocá-lo obliquamente.

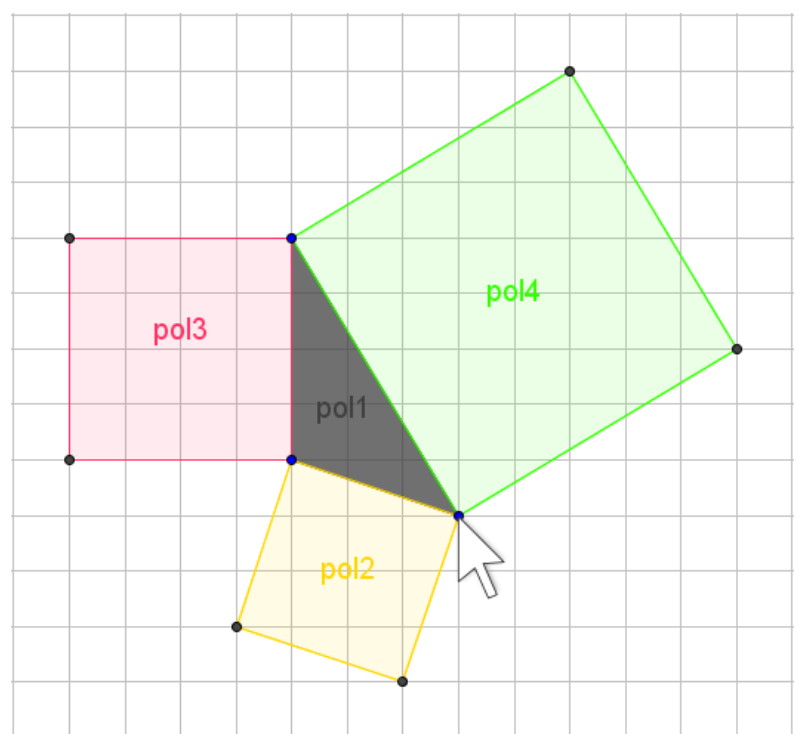

Figura 16 - Possível deformação na figura construída por Karina Fonte: $8^{\mathrm{a}}$ edição do Curso de GeoGebra

O problema descrito anteriormente pode ter sido imaginado por Hélio durante a análise do arquivo de Karina, pois sua sugestão visava evitar esse movimento dos pontos. 


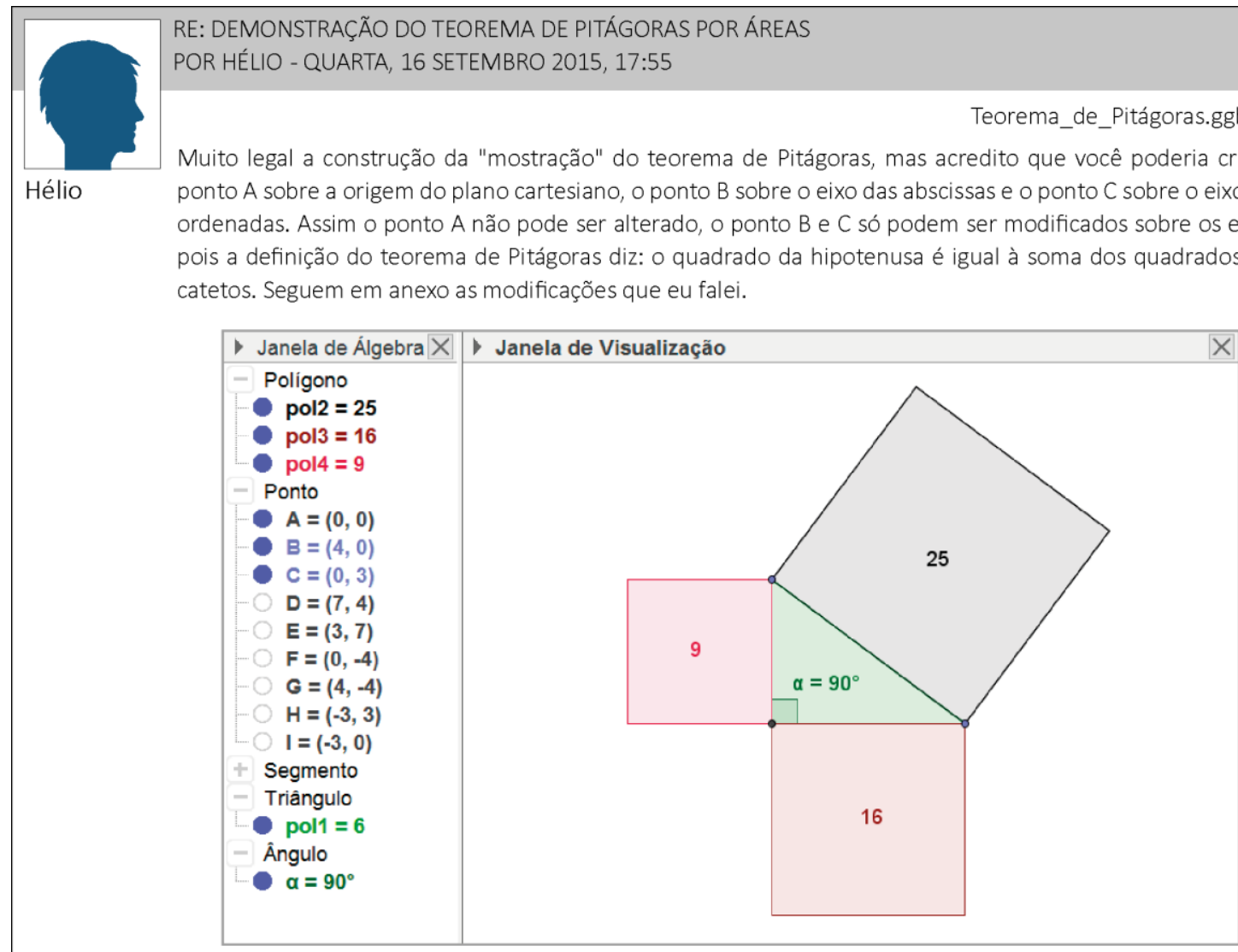

Figura 17 - Inserção de Hélio na postagem de Karina Fonte: $8^{\mathrm{a}}$ edição do Curso de GeoGebra

Além de sugerir certa limitação no deslocamento dos pontos B e C, e fixar o ponto A, Hélio fez com que os quadrados exibissem suas áreas na representação visual e não somente na Janela de Álgebra. E, por último, exibiu a medida do ângulo de $90^{\circ}$ que caracteriza um triângulo retângulo.

O cursista chamou de mostração do Teorema de Pitágoras a proposta apresentada por Karina. Daí, somos levados a inferir que ele pode acreditar que a demonstração deve ser realizada, utilizando outros recursos; talvez, utilizando símbolos e operações algébricas. Porém, não houve debate sobre essa observação ou provocação de Hélio.

Logo em seguida, Bruna escreveu sugestões para o arquivo postado por Hélio. E, na inserção seguinte, Karina se manifestou, concordando com as sugestões e alterações de Hélio.

RE: DEMONSTRAÇÃO DO TEOREMA DE PITÁGORAS POR ÁREAS
POR BRUNA-QUARTA, 16 SETEMBRO 2015, 23:12
Muito legal.
Vi que você ressaltou a área dos quadrados na figura. Acharia interessante fazer o mesmo com os lados.
$\begin{aligned} & \text { Para eles lerem mais facilmente que as áreas dos quadrados são dadas pelo quadrado dessas medidas e } \\ & \text { que eles leiam essas medidas observando também como medidas dos catetos e da hipotenusa. É só } \\ & \text { mesmo para ressaltar. Podíamos, depois, criar outros polígonos a partir dos lados e ver que a área. }\end{aligned}$




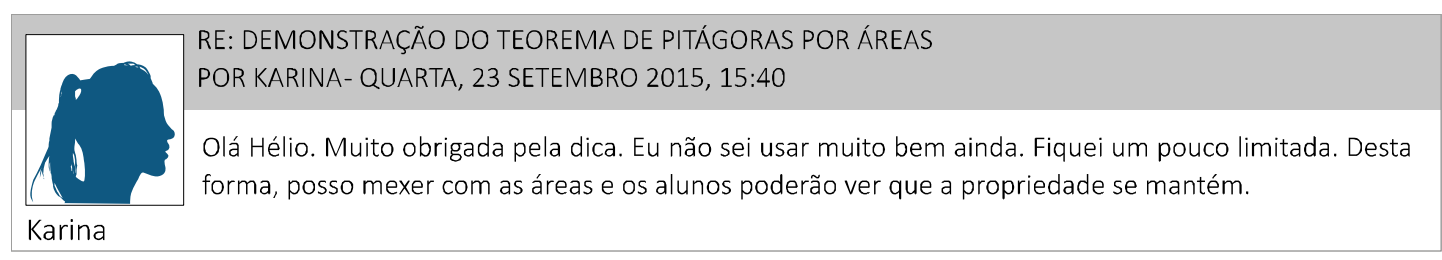

Figura 18 - Respostas de Bruna e Karina destinadas a Hélio na postagem de Karina Fonte: $8^{\mathrm{a}}$ edição do Curso de GeoGebra

A sugestão de Bruna era que fossem exibidas as medidas dos catetos e da hipotenusa do triângulo para que os alunos pudessem associar as áreas às medidas dos lados e, assim, estabelecessem relação entre o cálculo de área dos quadrados sobre os lados do triângulo e o Teorema de Pitágoras. Ela sugeriu, ainda, que, utilizando a ferramenta Polígonos Regulares, fossem construídos outros polígonos a partir dos lados do triângulo retângulo. Nessa construção, não se esperava que os alunos calculassem as áreas dos polígonos regulares, pois os valores são exibidos sobre cada um deles. A utilização do GeoGebra traria a possibilidade de associar o Teorema de Pitágoras a equações obtidas da soma das áreas de triângulos, quadriláteros, pentágonos, entre outros polígonos regulares, construídos sobre os lados de um triângulo retângulo (Figura 19).

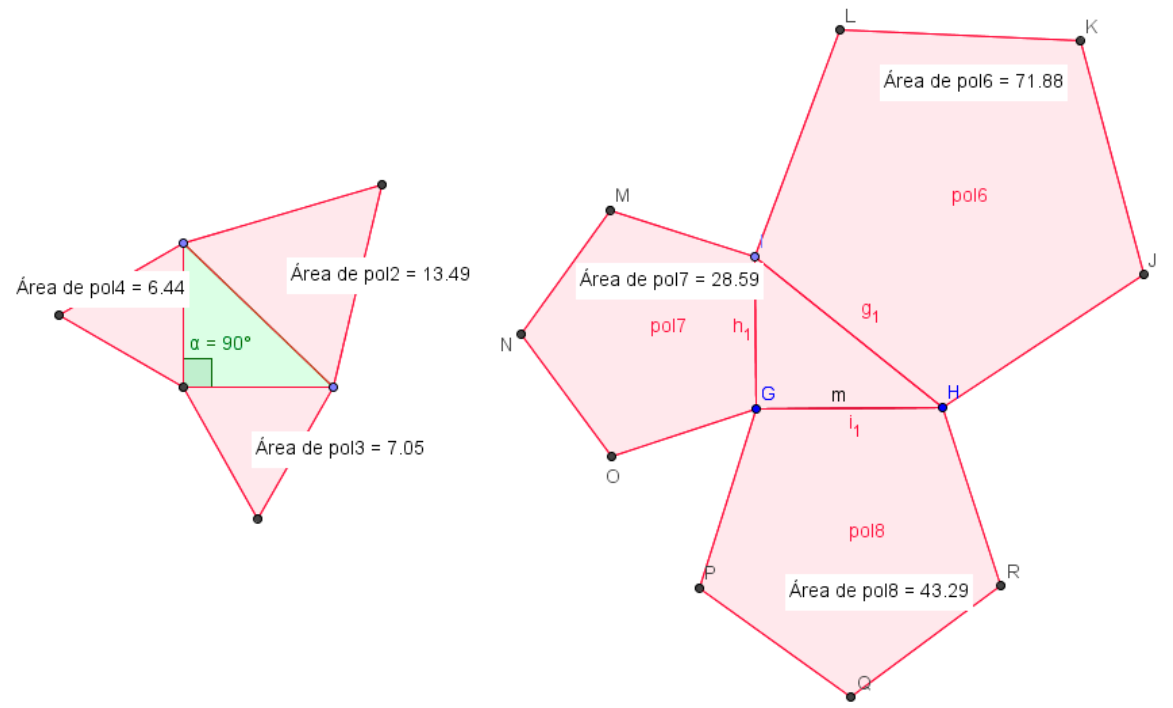

Figura 19 - Construções apresentadas no arquivo postado por Bruna em resposta a Karina Fonte: $8^{\mathrm{a}}$ edição do Curso de GeoGebra

Novas inserções vêm, em seguida, com outras sugestões e alterações no arquivo postado pelos cursistas que fizeram inserções anteriormente. 


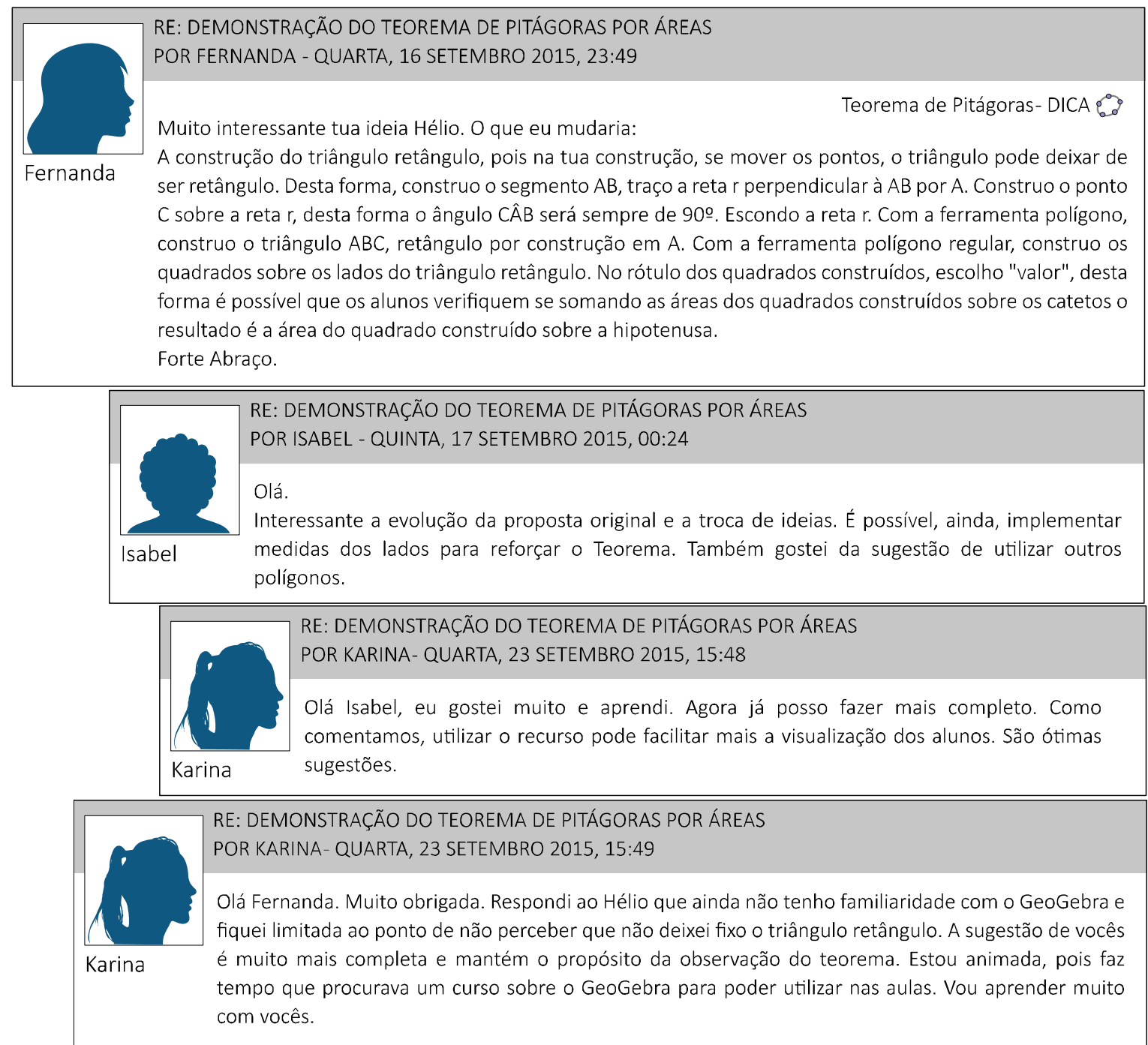

Figura 20 - Outras inserções na postagem de Karina seguidas por respostas escritas por Karina Fonte: $8^{a}$ edição do Curso de GeoGebra

Fernanda, analisando a proposta e o arquivo postado por Hélio, sugeriu outra forma de construção para ampliar as possibilidades de utilização. O resultado de sua construção permite posicionar o triângulo retângulo de tal maneira que os catetos não fiquem, apenas, um na vertical e outro na horizontal. Fernanda utilizou argumentos baseados em conhecimentos sobre Geometria Descritiva e, também, sobre modos de utilização do GeoGebra. Em um primeiro momento, ela construiu um segmento $\mathrm{AB}$ que depende de dois pontos livres (Figura 21):

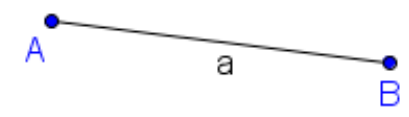

Figura 21 - Segmento AB construído por Fernanda Fonte: $8^{\mathrm{a}}$ edição do Curso de GeoGebra

A partir desse segmento, traçou uma reta perpendicular (r) em uma das extremidades (A). O próximo passo foi construir um ponto $\mathrm{C}$ sobre a reta perpendicular (Figura 22): 

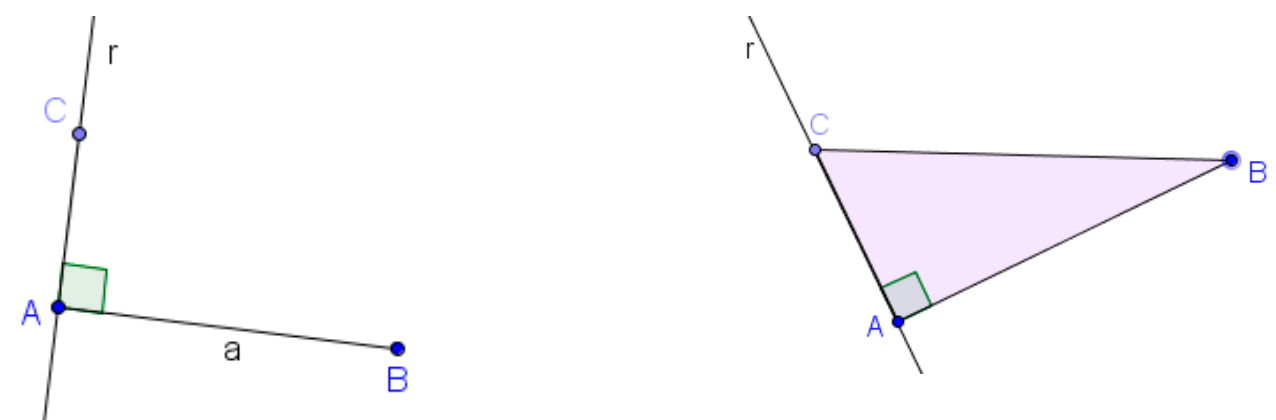

Figura 22 - Obtenção de um ângulo reto e, em seguida, de um triângulo retângulo Fonte: $8^{\mathrm{a}}$ edição do Curso de GeoGebra

Esse processo de construção faz com que o ponto $\mathrm{C}$ se desloque apenas sobre a reta $\mathrm{r}$. Com isso, os pontos A, B e C podiam ser movimentados sem que o polígono formado por eles deixasse de ser um triângulo retângulo.

Para finalizar sua construção, Fernanda utilizou a ferramenta Polígono Regular e construiu três quadrados a partir de cada par de pontos: (B, A), (C, B) e (A, C $)^{5}$ (Figura 23):

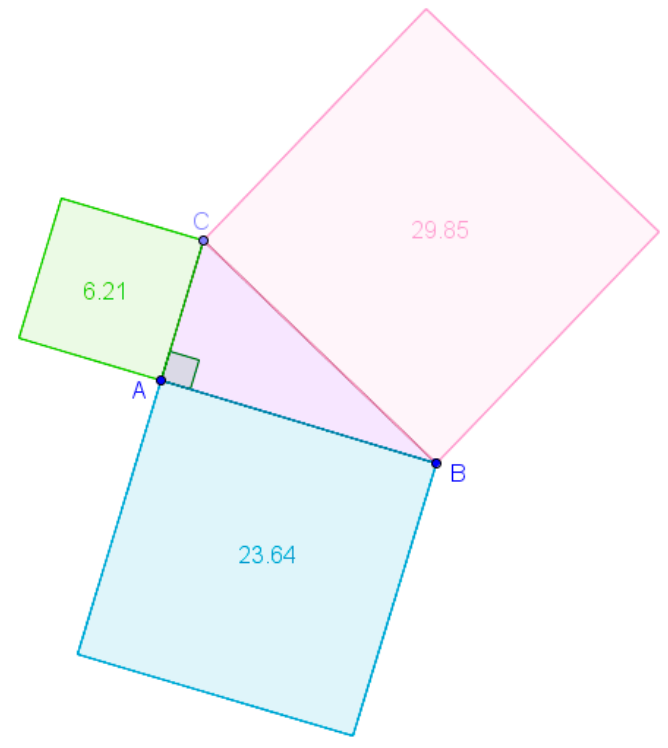

Figura 23 - Construção proposta por Fernanda para obter três quadrados a partir dos lados de um triângulo retângulo

Fonte: $8^{\mathrm{a}}$ edição do Curso de GeoGebra

Destacamos não apenas o aprimoramento de uma construção inicial, em termos de recursos técnicos, em comparação à construção obtida no final do processo. As inserções dos cursistas a partir da postagem de Karina levaram em conta um repertório de experiências de professores de realidades distintas que se traduzem em conhecimento matemático, conhecimento sobre ensino e aprendizagem de Matemática, conhecimento sobre o GeoGebra e, sobretudo, disposição ao descentramento (ver algo com os olhos do outro). E, assim, o

\footnotetext{
${ }^{5}$ A ferramenta Polígono Regular produz resultados diferentes de acordo com a ordem dos pontos. Assim, conforme apresentado na figura acima, Polígono[A, B, 4] obtém um quadrilátero desenhado sobre o segmento $\mathrm{AB}$ e Polígono[B, A, 4] obtém um polígono abaixo do segmento AB.
} 
fórum se transforma em um espaço em que o motivo da atividade de um cursista se transforma em um motivo coletivo, que, por sua vez, mobiliza um trabalho colaborativo.

\subsection{Postagem 3}

Na postagem apresentada nesta seção, o cursista Carlos manifestou algumas escolhas que dizem respeito a conteúdos, a materiais didáticos e a um método de ensino, baseado em uma investigação, ao descrever seu arquivo em sua postagem e, também, nas respostas enquanto dialogava com outros cursistas.

A construção foi realizada durante o Módulo 2 do Curso, e o enunciado da tarefa aparece na Figura 24:

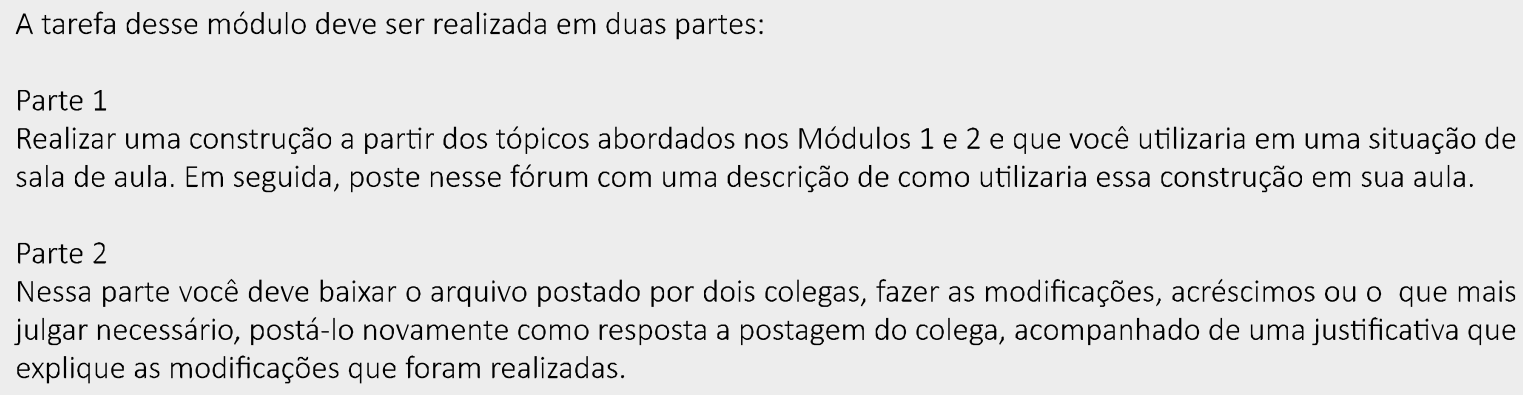

Figura 24 - Enunciado da Tarefa do Módulo 2 Fonte: $8^{\mathrm{a}}$ edição do Curso de GeoGebra

A partir de sua produção de significados para o enunciado acima, Carlos tinha em vista explorar os coeficientes $a, b$ e $c$ em duas equações $a x+b y+c=0$ e $y=a x+b$. Para isso, construiu um arquivo em que eram exibidas duas janelas de visualizações gráficas, simultaneamente. Em uma delas foi plotada a representação gráfica de ax + by $+c=0$ e na outra, de $y=a x+b$.

Os valores dos coeficientes, na proposta de Carlos, foram projetados para serem selecionados por meio de controladores gráficos, referidos internamente no GeoGebra como controles deslizantes. Assim, ao modificar o valor de um deles, ambos os gráficos seriam afetados. O arquivo final foi descrito por ele da seguinte forma: 


\begin{tabular}{|c|c|}
\hline & $\begin{array}{l}\text { EQUAÇÕES DA RETA } \\
\text { POR CARLOS - DOMINGO, } 27 \text { SETEMBRO 2015, 00:24 }\end{array}$ \\
\hline & Equaçoes da reta.ggb \\
\hline Carlos & $\begin{array}{l}\text { Construí três controles deslizantes }(a, b, c) \text { variando de-10 até } 10 \text { e com incremento } 1 \text {. Digitei a equalção ax + by + } \\
c=0 \text { no campo Entrada e obtive um gráfico na Janela de visualização. Clicando em inserir, usei a opção de exibir uma } \\
\text { segunda janela de visualização e construí a função } y=a x+b \text {. Os controles deslizantes servem simultaneamente } \\
\text { para as duas construções. } \\
\text { A tarefa dos alunos é investigar porque quando ambas assumem os mesmos valores dos coeficientes a, b e c, uma } \\
\text { fica crescente e a outra decrescente. }\end{array}$ \\
\hline
\end{tabular}

Figura 25 - Postagem de Carlos com arquivo anexo e descrição de sua construção Fonte: $8^{\mathrm{a}}$ edição do Curso de GeoGebra

Ao acessarem a postagem de Carlos e fazerem download do arquivo, os demais integrantes do grupo tinham acesso a uma construção com o seguinte layout (Figura 26):

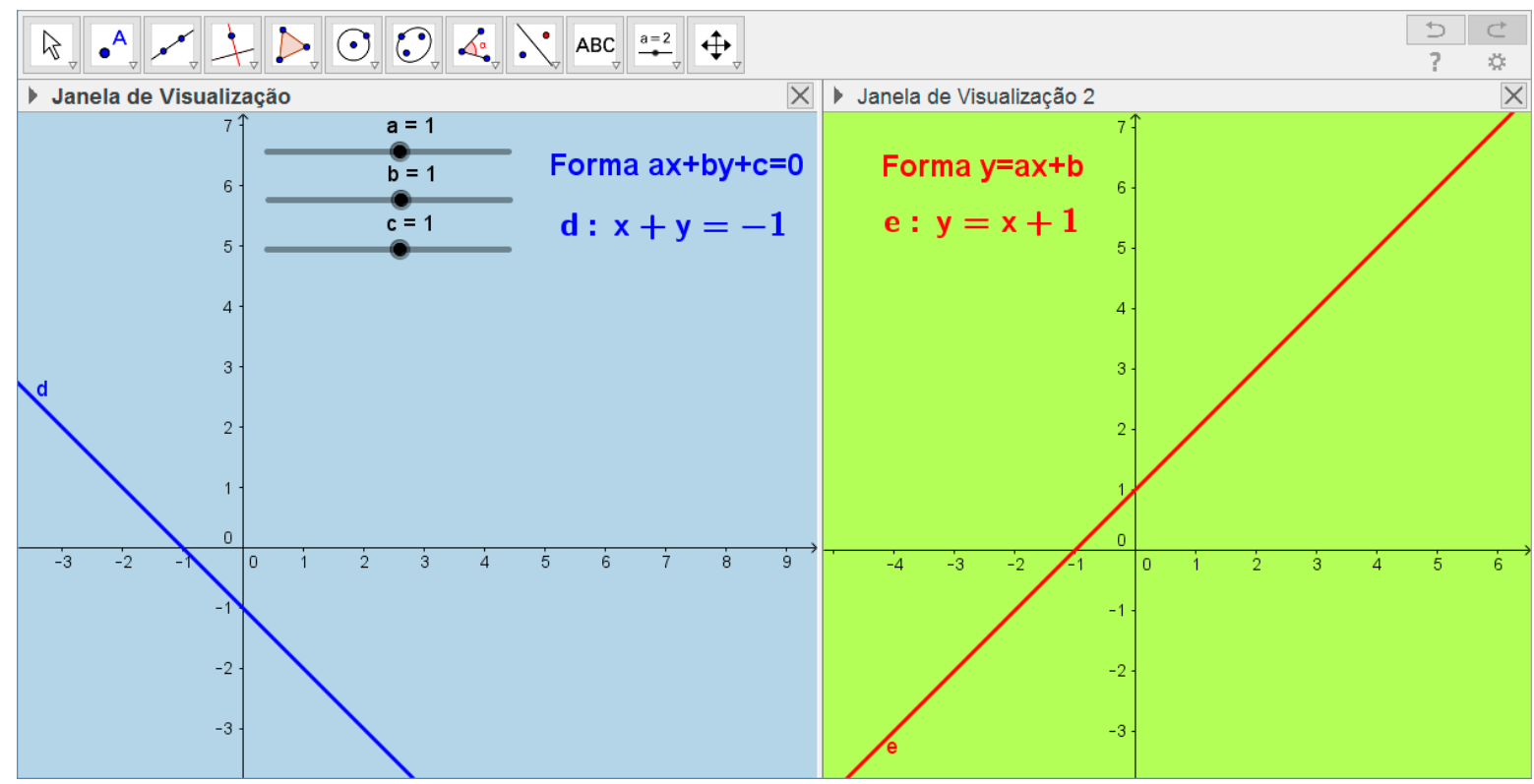

Figura 26 - Arquivo anexado a postagem de Carlos do Módulo 2 Fonte: $8^{a}$ edição do Curso de GeoGebra

Henrique fez a primeira inserção nessa postagem. Ele afirmou que foi motivado por uma curiosidade provocada pela postagem, e passou a investigar um problema que constituiu a partir do resíduo de enunciação do autor da postagem: descrição e arquivo anexado.

RE: EQUAÇÕES DA RETA
POR HENRIQUE - SEGUNDA, 28 SETEMBRO 2015, 19:58
Boa noite Carlos! Sua construção ativou minha infinita curiosidade. Me fiz a seguinte pergunta: será que
Sempre uma vai ser crescente e a outra decrescente?
$\begin{aligned} & \text { Futricando um pouco obtive a minha resposta que foi não. Se você posicionar os controles deslizantes em a=0, } \\ & \text { b=1 e c=-1, vai obter duas retas y=1 que não são crescentes nem decrescentes. } \\ & \text { Você poderia incluir essa questão na sua aula, se achar que convém. }\end{aligned}$




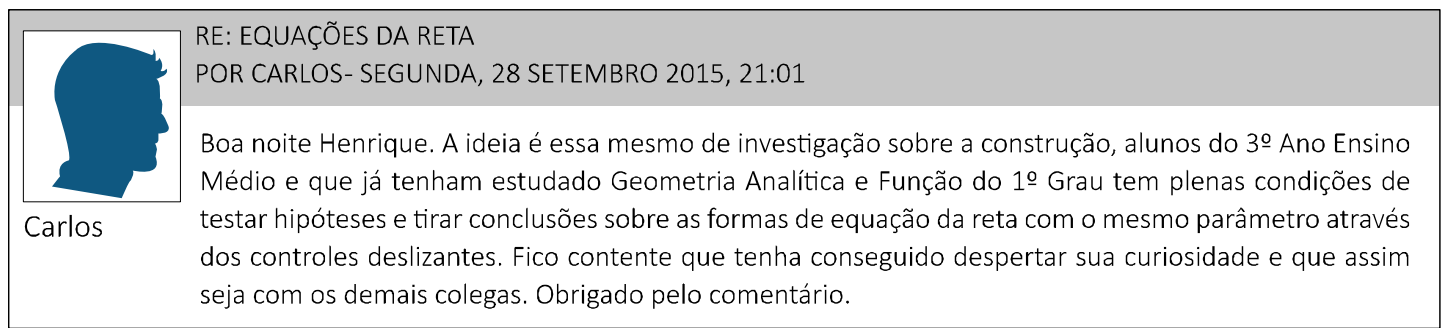

Figura 27 - Diálogo entre Henrique e Carlos na postagem de Carlos

Fonte: $8^{a}$ edição do Curso de GeoGebra

Carlos tinha uma hipótese que foi escrita na forma de uma proposição em sua postagem: quando ambas [as equações] assumem os mesmos valores dos coeficientes a, b e c, uma fica crescente e a outra decrescente. Para investigar essa hipótese em sala de aula, juntamente com seus alunos, escolheu um método: analisar o comportamento gráfico de duas equações simultaneamente. Tratava-se de uma abordagem geométrica que implicou em suas escolhas para construir o arquivo apresentado no fórum. A partir da abordagem desse problema, seus alunos e, também, outros integrantes do grupo, poderiam produzir significados para o efeito de cada coeficiente em ambas as equações.

Henrique parece ter aceitado o convite à pesquisa que lê na postagem de Carlos. E, com isso, encontrou um caso em que os gráficos não representam funções crescentes ou decrescentes.

Os registros de acesso ao ambiente de aprendizagem online mostram que Henrique fez 79 acessos às postagens de seus colegas de grupo no período de vigência do Módulo 2. Durante dez dias em que o módulo esteve ativo, ele visitou as postagens de todos os demais integrantes de seu grupo e, em seis delas, dialogou com o autor da postagem. Dentre essas, a postagem de Carlos.

Consideramos importante ressaltar que os participantes do curso, geralmente, manifestam, no processo de inscrição, a necessidade de desenvolvimento de conhecimentos técnicos a respeito do GeoGebra. Em outras palavras, esse é o motivo da atividade de formação na qual se inserem, ao iniciarem a participação no curso. Porém, devido às possibilidades de interação com outros colegas, criam, nos fóruns, um ambiente propício a outras discussões que favorecem:

- a construção colaborativa do conhecimento profissional;

- a inserção do cursista em diferentes situações de aprendizagem e frente a necessidade de se posicionar criticamente;

- o desenvolvimento e a análise de situações hipotéticas de ensino e de aprendizagem de Matemática. 
O diálogo promovido na comunidade online, a partir da postagem de Carlos, é compreendido por nós como um caso exemplar do que mencionamos anteriormente. Henrique e os demais colegas, que interagem com Carlos e entre si, não estão dialogando sobre conhecimentos técnicos do GeoGebra. Eles falam a respeito de conhecimentos matemáticos e sobre ensino e aprendizagem de Matemática.

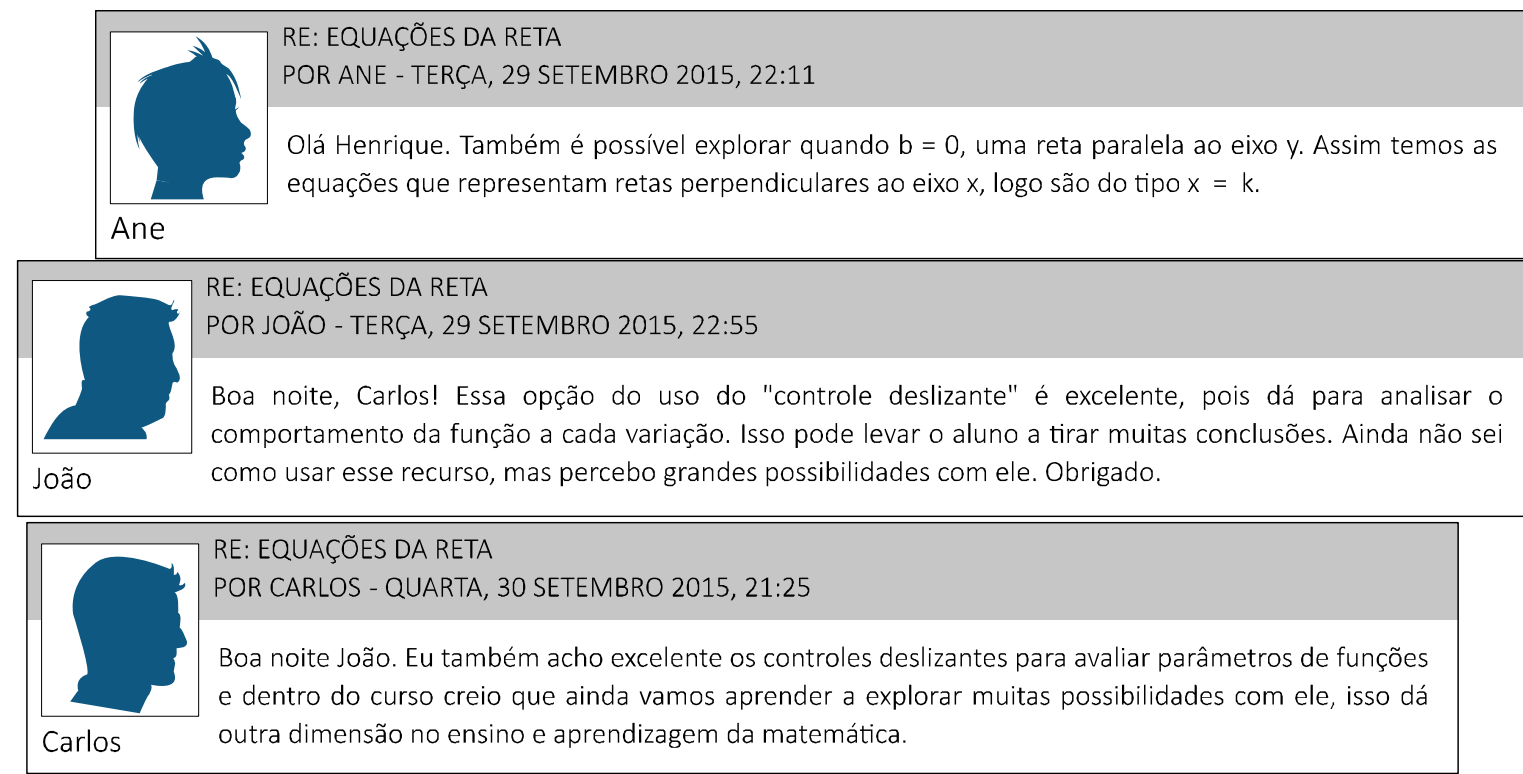

Figura 28 - Inserções de João e Ane na postagem de Carlos e, na sequência, a resposta de Carlos Fonte: $8^{\mathrm{a}}$ edição do Curso de GeoGebra

Sueli foi a única integrante do grupo que dialogou a respeito de conhecimentos técnicos a partir da construção de Carlos. Ela afirmou que conseguiu reproduzir a construção, seguindo os passos descritos por ele.

RE: EQUAÇÕES DA RETA
POR SUELI - QUINTA, 1 OUTUBRO 2015, 06:29
Bom dia Carlos. Achei muito legal sua ideia. Segui as explicações e consegui construir certinho, sem nenhuma
dificuldade. Sendo assim, não sugiro mudanças! Abraço.

Figura 29 - Inserção de Sueli seguida pela resposta de Carlos em sua postagem Fonte: $8^{\mathrm{a}}$ edição do Curso de GeoGebra

O processo descrito por Sueli, em que um cursista realiza uma construção ou produz novos conhecimentos a partir da postagem de outro cursista, é muito comum nos diálogos desenvolvidos nos fóruns. Como exemplo, em um tópico de outro fórum, Adriana iniciou sua postagem com a seguinte afirmação: 


TRIÂNGULO GIRANDO
POR ADRIANA - SÁBADO, 24 OUTUBRO 2015, 13:53
Boa tarde, pessoal! Confesso que já havia desistido de fazer esta tarefa, mas quando vi a construção do colega
Firando.ggb
Francisco (estrela giratória), consegui fazer algo. A partir das explicações dele construí um triângulo girando, para
isso segui os passos abaixo:
- Construí dois controles deslizantes
O primeiro chamei de alpha (variando de $1^{\circ}$ a $360^{\circ}$, com incremento $1^{\circ}$ ) e o segundo de n (variando de 1 a 100)
- Construí um triângulo
- Usei o comando sequência
S_1 = Sequência[Polígono[Girar[A, i $\alpha]$, Girar [B, i $\alpha]$, Girar[C, i $\alpha]], i, 1, n]$
Abraço. Adriana.

Figura 30 - Postagem de Adriana

Fonte: $8^{\mathrm{a}}$ edição do Curso de GeoGebra

A leitura de falas como essa leva a equipe formadora a entender que os arquivos e os textos produzidos pelos cursistas, nas dimensões individuais e coletivas das tarefas, funcionam para além de instrumentos de acompanhamento e avaliação dos participantes. São resíduos de enunciações que se integram às videoaulas e aos materiais textuais como recursos do curso. São frutos das enunciações dos cursistas [autores] sobre os quais outros cursistas [leitores] podem produzir conhecimentos.

\section{Para finalizar}

Conforme já mencionamos anteriormente, analisamos algumas postagens de um grupo de participantes de um curso. Para isso, realizamos uma pesquisa conforme critérios que descrevemos na seção Dados e método e lemos as postagens de tópicos criados nos fóruns dos módulos 1 a 10 da $8^{\text {a }}$ edição do Curso de GeoGebra. Essas leituras nos conduziram a algumas reflexões, que foram apresentadas nas seções Postagem 1, Postagem 2 e Postagem 3.

As três postagens selecionadas concentraram elementos sobre processos de aprendizagem dos cursistas, sobre materiais produzidos por eles e sobre algumas motivações para tais produções. Identificamos, ainda, alguns indicativos sobre os métodos de trabalho que desenvolviam e que se aperfeiçoavam dadas as características colaborativas do trabalho e, sobretudo, a disposição para interagir com outros cursistas e com a equipe formadora.

A postagem de Sueli, que apresentamos na seção anterior, chamou nossa atenção para algo que ainda não havíamos nos dado conta, até o momento que realizamos uma leitura sistemática das postagens. O texto de Sueli fez surgir a seguinte pergunta: qual é a dinâmica de acesso de um cursista quando realiza um tópico de estudo no curso? 
A equipe formadora sugere uma possibilidade: ao disponibilizar os materiais para estudo (videoaulas e textos) e, logo abaixo, o fórum de nome, tarefa, todos em uma mesma seção do ambiente de aprendizagem online, espera-se que o cursista assista, pelo menos, uma vez cada vídeo, e acesse o material textual que, em geral, complementa o que é abordado nas videoaulas. Na sequência, espera-se que o cursista leia o enunciado da tarefa, realize uma construção acompanhada de uma descrição e poste no fórum. Por último, interaja com outros cursistas por meio de comentários nas suas postagens e, também, responda aos questionamentos e comentários inseridos na sua postagem. Essa dinâmica de acesso é representada em sete passos na primeira linha da Figura 31. As outras três linhas representam as dinâmicas de acessos escolhidos por três cursistas do grupo pesquisado.

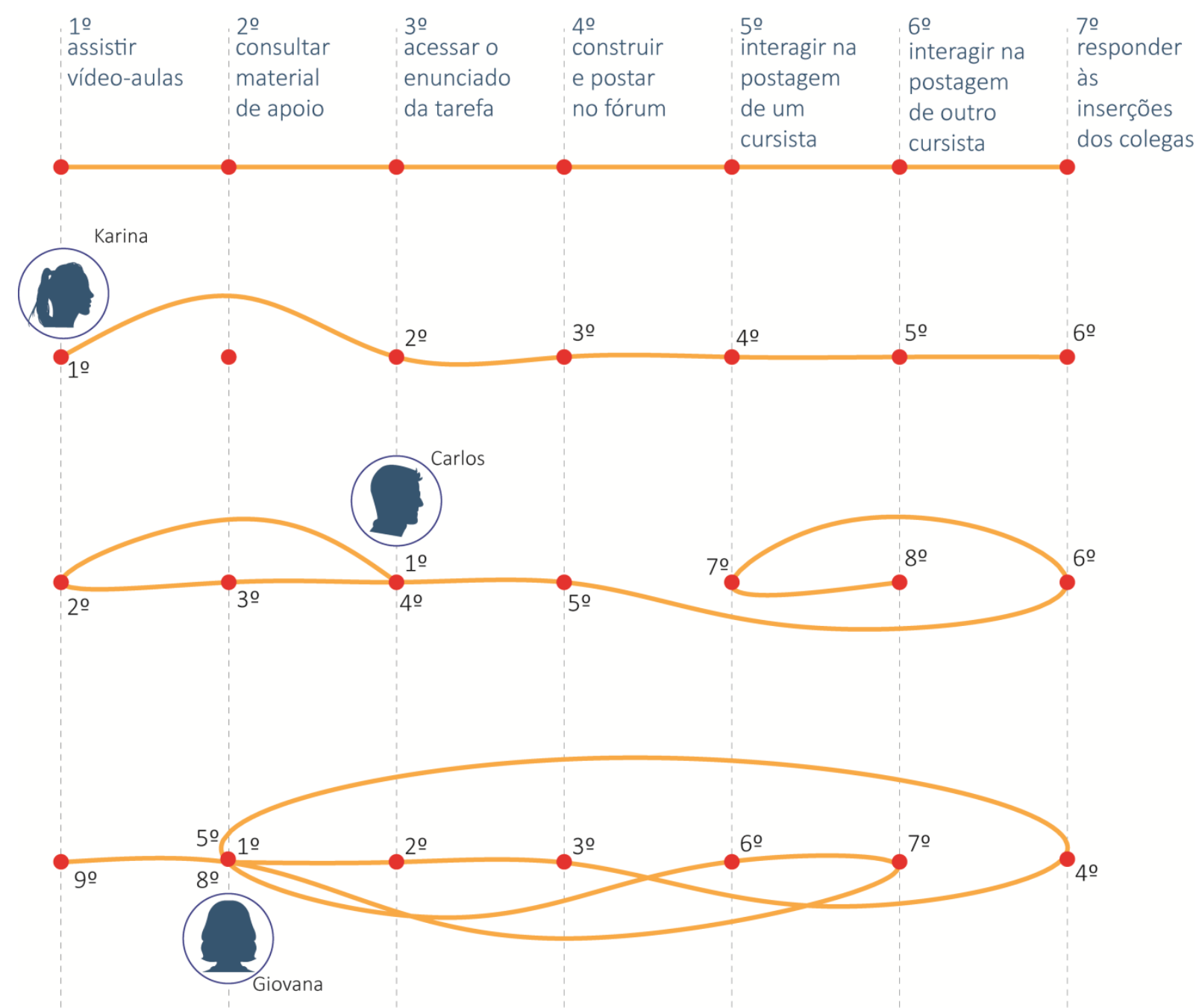

Figura 31 - Representação gráfica dos acessos de três cursistas em um módulo do curso Fonte: $8^{\mathrm{a}}$ edição do Curso de GeoGebra

Analisando os registros desses cursistas, foi possível perceber que eles adotam dinâmicas distintas. Karina, por exemplo, durante um módulo do curso adotou a dinâmica sugerida pelos formadores. Preferiu apenas não acessar o material textual. Carlos acessou, 
primeiramente, o enunciado da tarefa, por certo, para decidir sobre a quais tópicos de estudo deveria dedicar atenção especial para realizar o que era proposto na tarefa. Porém, após construir seu arquivo e postar no fórum, visitou várias vezes sua postagem e respondeu às perguntas e comentários de outros cursistas. Isso permitiu decidir com quais cursistas iria interagir quando fizessem suas postagens, o que veremos na análise que apresentamos a seguir.

Giovana iniciou os estudos, acessando o material textual. Depois, consultou o enunciado da tarefa, realizou sua construção e postou no fórum. De maneira semelhante a Carlos, respondeu a cada comentário e perguntas inseridos em sua postagem por outros participantes de seu grupo. Porém, é interessante notar que, após interagir com outros cursistas em sua própria postagem, ela retornou ao material textual. Inferimos, daí, que as provocações de seus colegas criaram demandas de estudos ou problematizaram suas afirmações de tal modo que ela necessitava rever alguns temas abordados pelos formadores.

Os registros de acesso revelam, ainda, outras escolhas realizadas pelos cursistas, que dizem respeito às redes que estabelecem ao interagirem em suas postagens, ao realizarem inserções nas postagens de outros cursistas, ou ainda, quando apenas visitam ou visualizam as postagens de seus colegas sem que desenvolvam qualquer diálogo com os autores.

Tomamos como exemplo as atividades desenvolvidas por Carlos durante o módulo 3. Sua postagem foi realizada no quinto dia de vigência desse módulo. Faltavam pouco mais de cinco dias para encerrar o módulo, momento em que há um aumento de acesso de cursistas ao ambiente online. Logo depois de ter realizado sua postagem, recebeu comentários de outros colegas e se concentrou em interagir com eles. O círculos azuis da Figura 32 representam seis cursistas que realizaram algum tipo de inserção na postagem de Carlos.

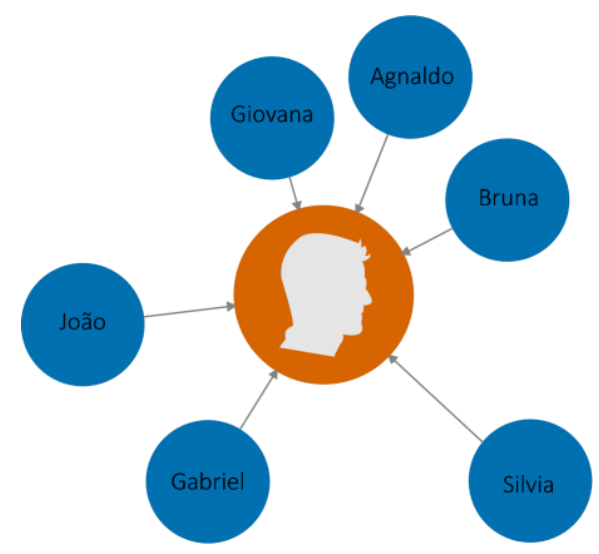

Figura 32 - Cursistas que fizeram inserções na postagem de Carlos durante o Módulo 3 Fonte: $8^{\mathrm{a}}$ edição do Curso de GeoGebra 
As interações desenvolvidas em sua postagem com aqueles colegas de curso, por certo, contribuíram para que Carlos escolhesse aqueles interagentes para debater sobre outros temas nas postagens que realizariam ou já haviam realizado. E, além desses, Carlos interagiu com outros dois cursistas, conforme sugerido no enunciado da tarefa. A Figura 33 mostra a rede de inserções de Carlos nas postagens de seus colegas de grupo.

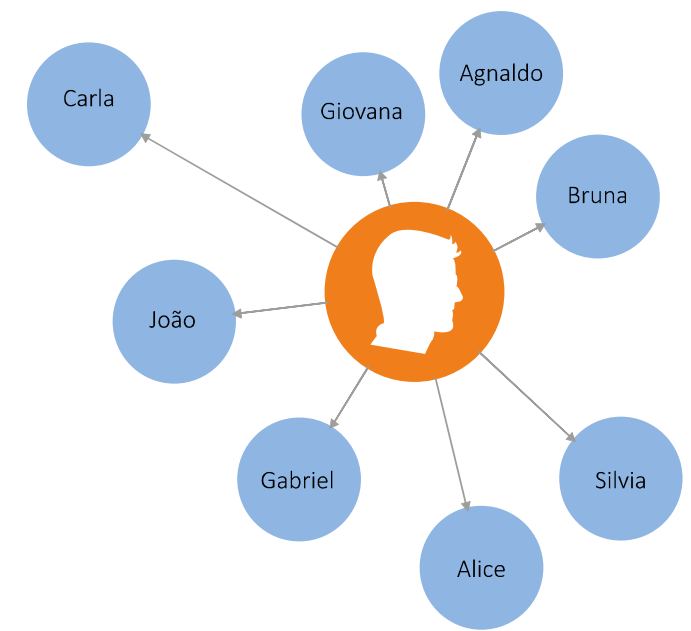

Figura 33 - Cursistas que tiveram inserções de Carlos em suas postagens durante o Módulo 3 Fonte: $8^{\mathrm{a}}$ edição do Curso de GeoGebra

Há, ainda, os casos em que Carlos visitou uma postagem, mas não dialogou com o autor ou com outro cursista que tenha realizado algum comentário. A nossa hipótese é que a discussão desenvolvida não era de seu interesse, ou alguma inserção naquela postagem já tinha a sugestão que ele faria, ou ainda, a discussão tratava de conhecimentos que poderiam não ser de seu domínio, entre outras possibilidades. Isso é observado não somente nos registros de Carlos, mas da maioria dos participantes (Figura 34). 


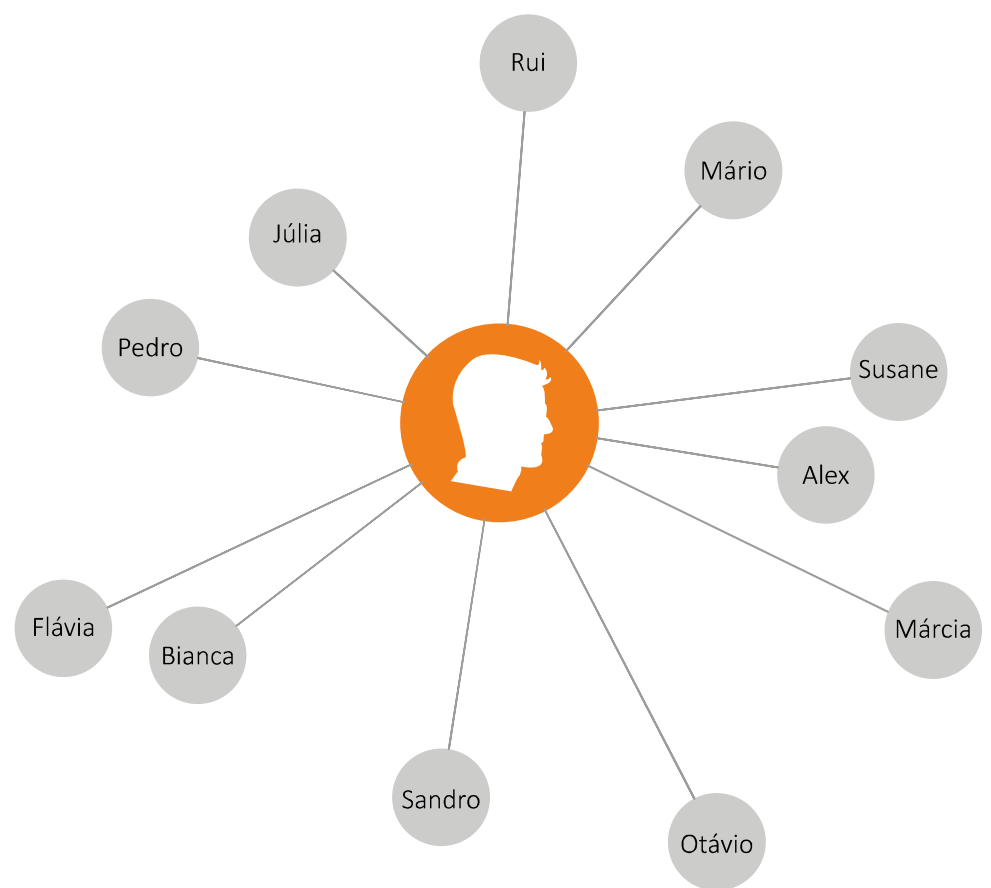

Figura 34 - Cursistas que tiveram suas postagens visualizadas por Carlos durante o Módulo 3 Fonte: $8^{\mathrm{a}}$ edição do Curso de GeoGebra

A Figura 35 expõe, graficamente, informações relativas aos acessos aos dez módulos do curso; apresenta duas barras para cada participante, a cinza com a quantidade de visitas sem escrever comentários, e a azul representa os casos em que escreveu comentários.

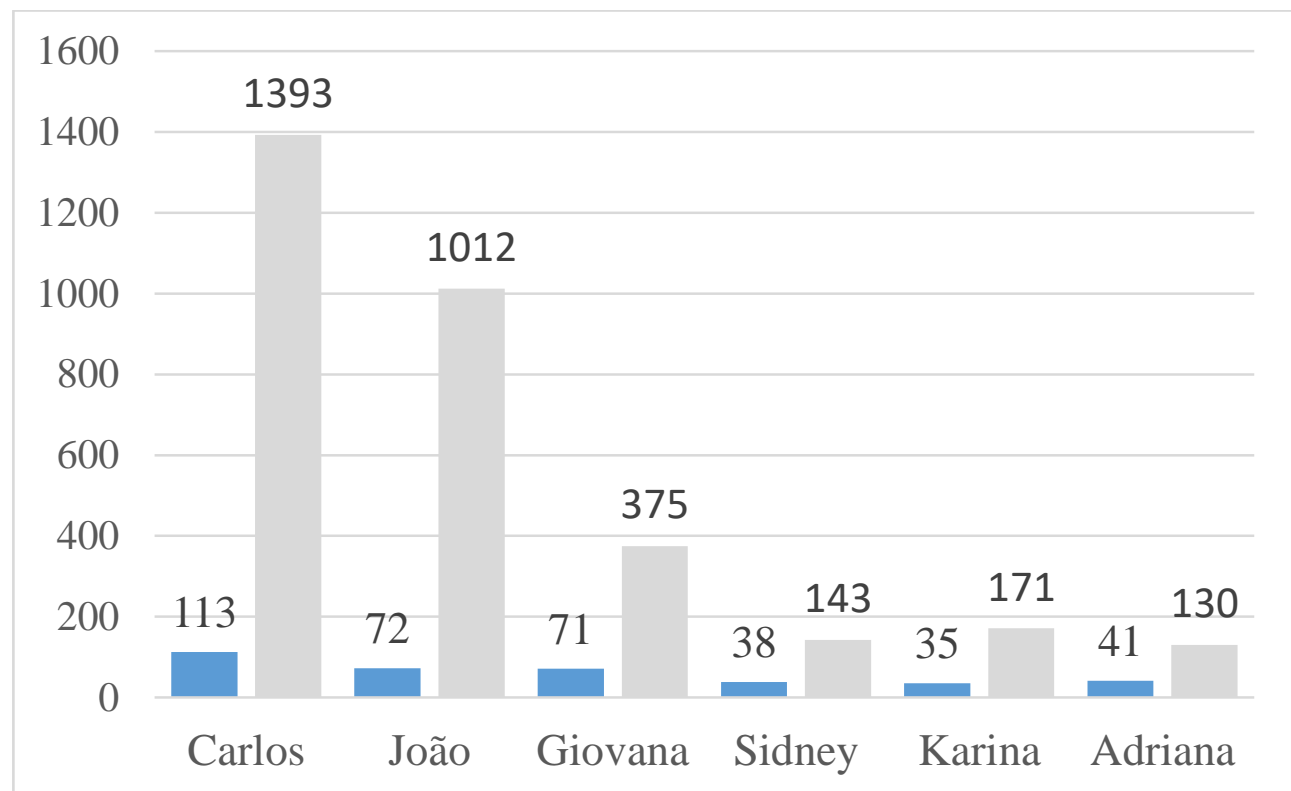

Figura 35 - Dados sobre visitas e inserções de seis cursistas durante a $8^{\text {a }}$ edição do Curso de GeoGebra Fonte: $8^{\mathrm{a}}$ edição do Curso de GeoGebra

$\mathrm{Na}$ avaliação final sobre o curso, alguns cursistas revelaram que visitam as postagens de outros colegas para fazer download do arquivo construído, para utilizar parte do que foi proposto a fim de resolver um problema em uma construção que pretendam realizar. Alguns 
afirmaram que reservam o endereço (url) de certas postagens para revisitá-las em outro momento, após concluir o curso, pois o ambiente de aprendizagem online fica disponível para acesso por tempo indeterminado.

E, finalmente, apresentamos a rede constituída em torno de Carlos em suas incursões durante o módulo 3 (Figura 36):

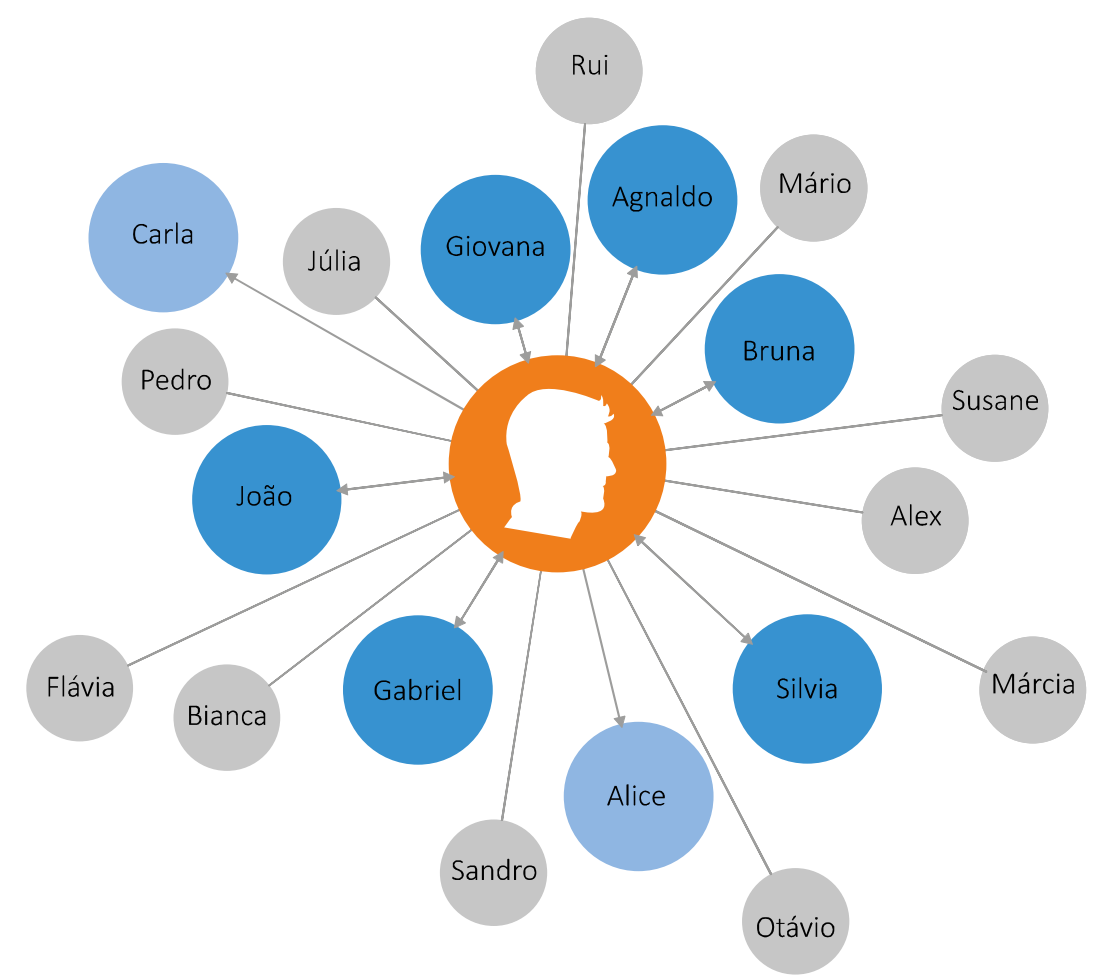

Figura 36 - Representação gráfica da rede formada a volta de Carlos no Módulo 3 Fonte: $8^{\mathrm{a}}$ edição do Curso de GeoGebra

As escolhas de Carlos e dos demais cursistas dependem de suas possibilidades de acesso ao ambiente de aprendizagem online, de sua atuação profissional, de gostos pessoais, o que foi compreendido por nós a partir de alguns depoimentos, durante a avaliação feita no final do curso.

A conclusão dos organizadores, diante da análise da dinâmica de interações e acessos, é que cabe a nós oferecer uma estrutura tecnológica e disparadores na forma de vídeos, textos, proposições de tarefas que permitam, a cada cursista, traçar um percurso à sua escolha e constituir redes colaborativas no interior da comunidade online.

Nossa proposta é que o cursista se integre a essa comunidade, que se auto-organiza a cada módulo, e que se disponha a interagir e a colaborar com seus pares, compreendendo essa forma de organização como necessária para a produção de novos conhecimentos matemáticos, conhecimentos sobre recursos tecnológicos e construções úteis à sala de aula. E essa é a nossa perspectiva para utilização de mídias sociais na formação de professores de Matemática. 


\section{Referências}

ASBAHR, F. da S. F. A pesquisa sobre a atividade pedagógica: contribuições da teoria da atividade. Revista Brasileira de Educação, Rio de Janeiro, n. 29, p. 108-118, maio/ago. 2005. Disponível em: <www.scielo.br/pdf/rbedu/n29/n29a09> Acesso em: 03 fev. 2015.

BARANAUSKAS, M. C. C.; MARTINS, M. C.; VALENTE, J. A. Codesign de Redes Digitais: tecnologias e educação a serviço da inclusão social. 1. ed. Porto Alegre: Penso, 2013. 304 p.

DANTAS, S. C. Pressupostos para formação de professores de matemática em um curso via web. Revista Perspectivas da Educação Matemática, Campo Grande, v. 8, n. 16, p. 308-331, 2015.

LEONTIEV, A. O desenvolvimento do psiquismo. 2. ed. Lisboa: Horizonte Universitário, 1978. 353 p.

LINS, R. C. Por que discutir teoria do conhecimento é relevante para a educação matemática. In: BICUDO, M. A. V. (Org.). Persquisa em Educação Matemática: concepções \& perspectivas. São Paulo: Ed. UNESP, 1999. p. 75-94.

LINS, R. C. Matemática, monstros, significados e educação matemática. In: BICUDO, M. A. V.; BORBA, M. D. C. Educação Matemática: pesquisa em movimento. São Paulo: Ed. Cortez, 2004. p. $92-120$.

LINS, R C. O modelo dos campos semânticos: estabelecimentos e notas de teorizações. In: ANGELO, C. L. et al. (Org.). Modelo dos Campos Semânticos e Educação Matemática: 20 anos de história. São Paulo: Ed. Midiograf, 2012. p. 11-30.

O GeoGebra. Disponível em: 〈http://ogeogebra.com.br〉. Acesso em: 01 jun. 2016.

Submetido em Junho de 2016. Aprovado em Novembro de 2016. 